\title{
Key unknowns in nitrogen budget for oil palm plantations. A review
}

\author{
Lénaïc Pardon $^{1} \cdot$ Cécile Bessou ${ }^{1} \cdot$ Paul Netelenbos Nelson ${ }^{2} \cdot$ Bernard Dubos $^{1}$. \\ Jean Ollivier $^{1}$ - Raphaël Marichal ${ }^{1,3}$. Jean-Pierre Caliman ${ }^{1,3} \cdot$ Benoît Gabrielle $^{4}$
}

Accepted: 27 January 2016/Published online: 29 February 2016

(C) INRA and Springer-Verlag France 2016

\begin{abstract}
Nitrogen $(\mathrm{N})$ losses in agroecosystems are a major environmental and economic issue. This issue is particularly pronounced in oil palm cultivation because oil palm production area is expected to increase to 12 Mha by 2050 . N fertilization in oil palm plantations is mainly provided by mineral fertilizers, palm oil mill by-products, and biological fixation using legume cover crops. $\mathrm{N}$ loss has a major environmental impact during cultivation. For instance, $48.7 \%$ of the greenhouse gases emitted to produce $1 \mathrm{t}$ of palm oil fruit are due to $\mathrm{N}$ fertilization. Actually, there is little comprehensive knowledge on how to calculate $\mathrm{N}$ budgets in oil palm plantation in order to optimize fertilization, taking into account $\mathrm{N}$ leaching and $\mathrm{N}$ gases emissions. Here we modeled knowledge about all $\mathrm{N}$ fluxes in an oil palm field following standard management practices of industrial plantations, on a mineral soil, from planting to felling after a 25 -year-growth cycle. The largest fluxes are internal fluxes, such as oil palm uptake, with 40 $380 \mathrm{~kg} \mathrm{~N} \mathrm{ha}^{-1}$ year $^{-1}$, and the decomposition of felled palms at the end of the cycle, with $465-642 \mathrm{~kg} \mathrm{~N} \mathrm{ha}^{-1}$. The largest losses are emissions of $\mathrm{NH}_{3}$ and leaching of $\mathrm{NO}_{3}{ }^{-}$, corresponding to $0.1-42 \%$ and $1-34 \%$ of mineral $\mathrm{N}$ applied, respectively. The most uncertain and least documented fluxes
\end{abstract}

Cécile Bessou

cecile.bessou@cirad.fr CIRAD, UPR Systèmes de pérennes, F-34398 Montpellier, France

2 College of Science, Technology and Engineering, James Cook University, Cairns, Australia

3 SMART Research Institute, Jl. Tengku Umar 19, Pekanbaru 28112, Indonesia

4 AgroParisTech, INRA, UMR EcoSys, 78850 Thiverval-Grignon, France are $\mathrm{N}$ losses such as $\mathrm{N}_{2} \mathrm{O}, \mathrm{NO}_{x}, \mathrm{~N}_{2}$ emissions, leaching, $\mathrm{NH}_{3}$ volatilization, and runoff. The most critical conditions for $\mathrm{N}$ losses occur during the immature phase when young palms uptake is low and during the mature phase in areas with sparse soil cover or receiving high amounts of fertilizers. Data is lacking about the effects of management practices on $\mathrm{NO}_{3}{ }^{-}$ leaching and $\mathrm{N}_{2} \mathrm{O} / \mathrm{NO}_{x}$ emissions in those critical conditions.

Keywords Oil palm $\cdot \mathrm{N}$ budget $\cdot \mathrm{N}$ losses $\cdot$ Tropical perennial crop

\section{Contents}

1. Introduction

2. $\mathrm{N}$ budget within oil palm management

2.1. Standard oil palm management

2.2. Application of $\mathrm{N}$ budgets to fertilizer management

2.3. System boundaries and accounted fluxes

3. $\mathrm{N}$ fluxes and variability in plantations: state-of-the-art

3.1. Inputs

3.1.1. Biological $\mathrm{N}$ fixation

3.1.2. $\mathrm{N}$ fertilizers

3.1.3. $\mathrm{N}$ depositions

3.2. Internal fluxes

3.2.1. N uptake

3.2.2. $\mathrm{N}$ from plant residues to the litter

3.2.3. $\mathrm{N}$ from the litter to the soil

3.3. Outputs 
3.3.2. N leaching

3.3.3. N losses through runoff and erosion

3.3.4. $\mathrm{N}$ gaseous losses

4. Important fluxes and critical conditions for $\mathrm{N}$ losses

4.1. The most important and most uncertain fluxes

4.2. Critical conditions for $\mathrm{N}$ losses

5. Discussion and key research needs

6. Conclusions

\section{Introduction}

The anthropogenic production of reactive nitrogen $(\mathrm{Nr})$ is now two to three times that of natural terrestrial sources. Much of this nitrogen (N) is lost from the site of use to the surrounding environment, resulting in a cascade of negative environmental impacts (Vitousek et al. 1997; Galloway et al. 2013). In agriculture in particular, $\mathrm{N}$ losses are a key issue from both environmental and economic points of view. Agroecosystems receive about $75 \%$ of the $\mathrm{Nr}$ created by human activity (Galloway et al. 2008; Foley et al. 2011; Galloway et al. 2013).

In oil palm plantations, addition of $\mathrm{N}$ via legume cover crops and fertilizers is a common practice to achieve the yield potential of the crop. Fertilizers constitute 46 to $85 \%$ of field costs in a plantation (Caliman et al. 2001a; Goh and Po 2005; Silalertruksa et al. 2012; Goh and Härdter 2003). Addition of $\mathrm{N}$ is also associated with pollution risks of ground and surface waters and emission of greenhouse gases (Choo et al. 2011; Comte et al. 2012). This raises environmental concerns as oil palm is the most rapidly expanding tropical perennial crop and is expected to keep expanding in the next decades up to an added 12 Mha area by 2050 (Corley 2009), i.e., +64 \% compared to current surface area (18.7 Mha in FAOstat 2014). Hence, an accurate understanding of $\mathrm{N}$ dynamics and losses in plantations is important to optimize the management of $\mathrm{N}$ and use of $\mathrm{N}$ fertilizers.

$\mathrm{N}$ budgets are commonly used in palm plantations to make fertilizer management plans. The used approach may be more or less complex depending on how detailed the budget is in terms of $\mathrm{N}$ flux accounting. Oil palm is a perennial crop with a wide root network and a high production of biomass residues, which, coupled with management practices, generates spatial and temporal heterogeneity in soil dynamics over the long growing cycle. Hence, a precise assessment of $\mathrm{N}$ budget requires characterizing and modeling numerous and diverse fluxes.
Despite existing data on measurements over the last 50 years, there has been no comprehensive synthesis on the $\mathrm{N}$ cycle in oil palm plantations and the effects of environmental conditions and management practices on $\mathrm{N}$ losses. There is a need to compile such data and to highlight research needs in order to shed further light on $\mathrm{N}$ budgets in oil palm plantations and to improve fertilizer management in a sustainable way.

This paper focuses on oil palm industrial plantations on mineral soils after replanting. The objectives are to (a) assess current knowledge regarding the $\mathrm{N}$ cycle in oil palm plantations, (b) identify the remaining challenges for establishing complete $\mathrm{N}$ budgets and, in particular, quantify $\mathrm{N}$ losses, and (c) identify opportunities for the use of $\mathrm{N}$ budgets to improve production and environmental outcomes. This paper first reviews the budget approaches and highlights the peculiarities of oil palm plantations. It then reviews the existing literature, measurements, and knowledge gaps on $\mathrm{N}$ fluxes in plantations. It finally identifies dominant processes and critical conditions favoring $\mathrm{N}$ losses.

\section{$2 \mathrm{~N}$ budget within oil palm management}

\subsection{Standard oil palm management}

In this paper, we consider predominant management practices in large industrial plantations, as they are generally related with highest environmental impacts (Lee et al. 2014a). Moreover, practices in independent smallholders' plantations may be more variable and are less characterized in the literature (Lee et al. 2014b). However, a large part of smallholders' plantations in Asia and South America are supervised by industrial plantations in the young age of the palms, and their practices are hence partly comparable to the industrial plantations. In industrial plantations, practices also vary, as for the choice of the planting material, the rate and placement of mineral and organic fertilizers, the weeding practices, etc. But some practices have a relatively lower variability, such as planting density, duration of the growth cycle, and sowing of a legume cover. Therefore, we considered the management practices being the most spread, which we referred to as standard management practices in this paper.

$\mathrm{N}$ cycling in oil palm plantations must be considered in the context of management systems, which we briefly summarize here. This summary is derived from (Corley and Tinker 2003), and we refer readers to that book for more detailed insights. Palm plantations are generally grown on a cycle of approximately 25 years. Clearing and preparation practices may differ depending on the landform and previous land cover. Important variations for $\mathrm{N}$ cycling concern the amount of residues from the previous vegetation left to decompose in the field, as well as anti-erosion measures and drain density. One-year-old palms from a nursery are planted in equilateral triangular 
spacing with a planting density usually in the range of 120 160 palm.ha ${ }^{-1}$. A legume cover, e.g., Pueraria phaseoloides or Mucuna bracteata, is generally sown in order to provide quick ground cover and fix $\mathrm{N}$ from the atmosphere. The legume rapidly covers the whole area and is controlled with manual weeding around palms. It declines as the oil palm canopy grows and is at least partially replaced by more shade-tolerant vegetation around the sixth year when the palm canopy closes.

During the first 2-3 years of plantation, i.e., the immature phase, fruit bunches are not harvested and female inflorescences may be removed to improve growth and subsequent production at the beginning of the third year after planting. During the following 22 years, i.e., the mature phase, the plantation is harvested two to four times per month. For each fresh fruit bunch harvested, one or two palm fronds are pruned and left in the field, mostly in windrows in every second interrow. The alternate inter-row is used for the harvest pathway. The natural vegetation cover in the harvest path and in the circle around the palms is controlled three to four times a year with selective chemical or mechanical weeding. In the remaining area, vegetation is left to grow, except for woody weeds to avoid critical competition with the oil palms.

Fertilizer management varies greatly between plantations and through the life cycle. It generally consists of the application of various forms of mineral fertilizers containing N, P, K, $\mathrm{Mg}, \mathrm{S}, \mathrm{B}, \mathrm{Cl}$, but can be also complemented or substituted by organic fertilizers. Organic fertilizers come mainly from the palm oil mill. After oil extraction, the empty fruit bunches and the palm oil mill effluent may be returned, either fresh or after co-composting, to parts of the plantation, especially on poor soils or in the vicinity of the mill. Around 25 years after planting, the productivity of the palms declines due to higher fruit lost and higher harvesting cost, depending on the palms' height and stand per hectare. The old palms are felled and sometimes chipped and left in the field to decompose, and new seedlings are planted between them.

Based on this standard management, we identified three main peculiarities in $\mathrm{N}$ dynamics to be accounted for in the oil palm $\mathrm{N}$ budget. These characteristics are related both to the lifespan of the crop and the management practices. First, as a perennial crop, the palm grows continuously for around 25 years and develops a wide root network, whose extent and turnover will impact nutrient uptake efficiency. Practices are adapted to the plants' evolving needs and may vary from year to year. Thus, $\mathrm{N}$ dynamics may be impacted differently each year and may be influenced by both short- and long-term processes. Second, management practices are spatially differentiated and generate marked spatial heterogeneity across the plantation. For instance, mineral and organic fertilizers may be unevenly distributed and weeds are controlled in specific areas. Thus, the practices generate three main visible zones on the ground: the weeded circle, the harvest pathway, and the pruned frond windrows. These zones differ in terms of ground cover, soil organic matter content, bulk density, and soil biodiversity (Carron et al. 2015; Nelson et al. 2015), and the differences become more pronounced over the crop cycle. $\mathrm{N}$ dynamics must also be related to the distribution of fertilizer, which may or may not be associated with the visible zones. $\mathrm{N}$ fertilizer may be applied manually or mechanically usually as a band around the outside of the weeded circle. Empty fruit bunches are usually applied in piles adjacent to the harvest path. Temporal and spatial heterogeneity may both influence $\mathrm{N}$ dynamics and may also affect the measurement accuracy of $\mathrm{N}$ fluxes and stocks (Nelson et al. 2014). Third, internal fluxes of $\mathrm{N}$ within the plantation may be important. For instance, as a tropical perennial crop, oil palm produces a large amount of biomass that is returned to the soil, with large associated $\mathrm{N}$ fluxes such as pruned fronds, empty fruit bunches, and felled palm. There are also internal fluxes within the palm tree itself, notably from old to new fronds.

\subsection{Application of $\mathrm{N}$ budgets to fertilizer management}

$\mathrm{N}$ budgets or balances are based on the principle of mass conservation (Legg and Meisinger 1982; Meisinger and Randall 1991). In agroecosystems, this principle can be represented as follows: $\mathrm{N}$ inputs $=\mathrm{N}$ outputs $+\Delta \mathrm{N}$ storage. This simple principle can lead to various approaches, whose complexity increases with the number of considered fluxes and the accuracy of the calculation (Fig. 1). Watson and Atkinson (1999) and Oenema et al. (2003) proposed a distinction between three basic approaches in nutrient budget studies: (1) farm-gate budgets, which record only the fluxes of purchased nutrients entering and fluxes of harvested nutrients leaving the system; (2) system budgets, which also include natural fluxes of nutrients entering and leaving the system such as biological $\mathrm{N}$ fixation or $\mathrm{N}$ leaching, but without looking at potential internal dynamics; (3) cycling models, which take into account all fluxes entering and leaving the system and also quantify internal fluxes and stocks, e.g., immobilization in plants and mineralization of residues.

$\mathrm{N}$ budgets are commonly used to determine crop fertilizer management. The reliability and applicability of $\mathrm{N}$ budget approaches in the case of oil palm management are shown in Fig. 1. Reliability proceeds from a combination of accuracy and precision, which increase with the level of knowledge and data availability. On the contrary, applicability is usually limited by knowledge and data availability. Applying one of these approaches to fertilizer management hence implies some tradeoff between reliability and applicability. In oil palm plantations, only the first two approaches are currently commonly used, i.e., farm-gate or system budgets, or an intermediate partial budget approach. A comprehensive nutrient cycling approach exists, i.e., the WANULCAS model (Noordwijk et al. 2004), but is still not yet widespread in practice. In the 
Fig. 1 Nature of $\mathrm{N}$ budget to guide management. Reliability increases when accuracy and precision increase, but applicability decreases with data requirement. The various approaches are adapted to oil palm management context

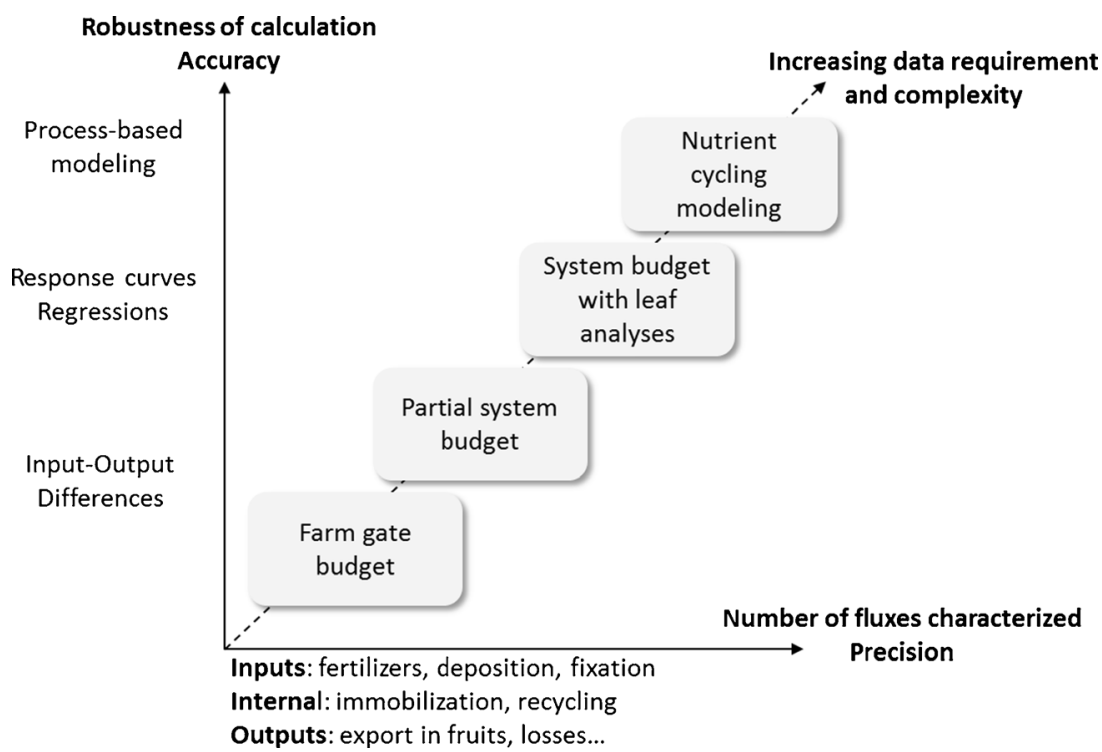

as well as better accounting for the specificities of various planting materials in these internal nutrient dynamics (Ollivier et al. 2013). Indeed, in tree crops, storage and relocations of nutrients may occur between different plant tissues. It is therefore important to understand the fluxes inside the plant over the cycle, in order to link more efficiently the nutrient content, the rate of fertilizers to apply, and the targeted yield. These relationships also depend on soil and climate conditions, notably in the case of palm oil (Foster 2003).

Depending on the precision and accuracy of the measurements and calculations, $\mathrm{N}$ budgets may also be used to identify dominant processes or knowledge gaps and to estimate $\mathrm{N}$ losses as a performance indicator in nutrient management or in environmental impact assessment. As an example, in the greenhouse gas calculator, PalmGHG (Bessou et al. 2014), developed by Roundtable on Sustainable Palm Oil (RSPO), a partial $\mathrm{N}$ budget approach based on the IPCC guidelines was applied in order to estimate the $\mathrm{N}$ losses in a plantation. As part of these losses, $\mathrm{N}_{2} \mathrm{O}$ emissions are calculated based on a statistical model that correlated $\mathrm{N}_{2} \mathrm{O}$ losses to the total mineral and organic $\mathrm{N}$ fertilizers applied (see "Response curves, Regressions" in Fig. 1).

While the simplest forms of budget may be easy to implement for fertilizer management, they neither show where $\mathrm{N}$ is stored nor the time scale of its availability, e.g., for the organic $\mathrm{N}$ in soil (Watson and Atkinson 1999). On the contrary, the cycle modeling approach encompasses all fluxes including internal $\mathrm{N}$ dynamics and $\mathrm{N}$ losses at any time. In the following sections, we investigate the available knowledge to characterize all fluxes within a cycle modeling approach and highlight research needs to fill in knowledge gaps and improve fertilizer management based on comprehensive cycling models or derived budget approaches. 


\subsection{System boundaries and accounted fluxes}

The fluxes were investigated within the system boundaries of an oil palm field on a mineral soil, including the following components: palms, ground vegetation cover, litter, and soil where the roots are. The production of agricultural inputs, transport-related fluxes, and the process of milling were not included in the system. The pools, stocks, and fluxes of $\mathrm{N}$ considered are shown in Fig. 2.

Spatially, the system was defined as having homogeneous palm and ground vegetation cover types and age, soil, climate, and management. Regarding the root zone, roots were measured down to 3-5 m depth (Jourdan and Rey 1997; Schroth et al. 2000; Sommer et al. 2000). But most of the root biomass and root activity is found in the top $1 \mathrm{~m}$ ( $\mathrm{Ng}$ et al. 2003; Corley and Tinker 2003), with for instance $75 \%$ of root activity estimated at $0.8 \mathrm{~m}$ depth in Papua New Guinea (Nelson et al. 2006) and $0.22 \mathrm{~m}$ in Malaysia (Lehmann 2003 using data from IAEA 1975).
Temporally, the system included the whole growth cycle of the palms, from planting to felling, excluding the nursery stage and previous land use. The typical 25-year-growth cycle is split into two main phases: the immature phase that starts when previous palms are felled and ends 2-3 years later and the mature phase from then until the end of the cycle when the palms are felled.

Several inputs, internal fluxes and outputs or losses occur along with transformations to the form of $\mathrm{N}$. Inputs to the system consist of biological $\mathrm{N}$ fixation; mineral and organic fertilizer application such as empty fruit bunches, palm oil mill effluent, or compost; atmospheric deposition of ammonia $\left(\mathrm{NH}_{3}\right)$ and $\mathrm{N}$ oxides $\left(\mathrm{NO}_{x}\right)$; and deposition of eroded $\mathrm{N}$ containing soil and litter coming from outside of the system. Internal fluxes comprise $\mathrm{N}$ uptake by palms; legumes and other vegetation; $\mathrm{N}$ transfer to the litter and soil via residues from palms such as pruned fronds, removed inflorescences, frond bases, root exudates, roots turnover, and the whole palm at the end of the cycle; legumes and other vegetation such as

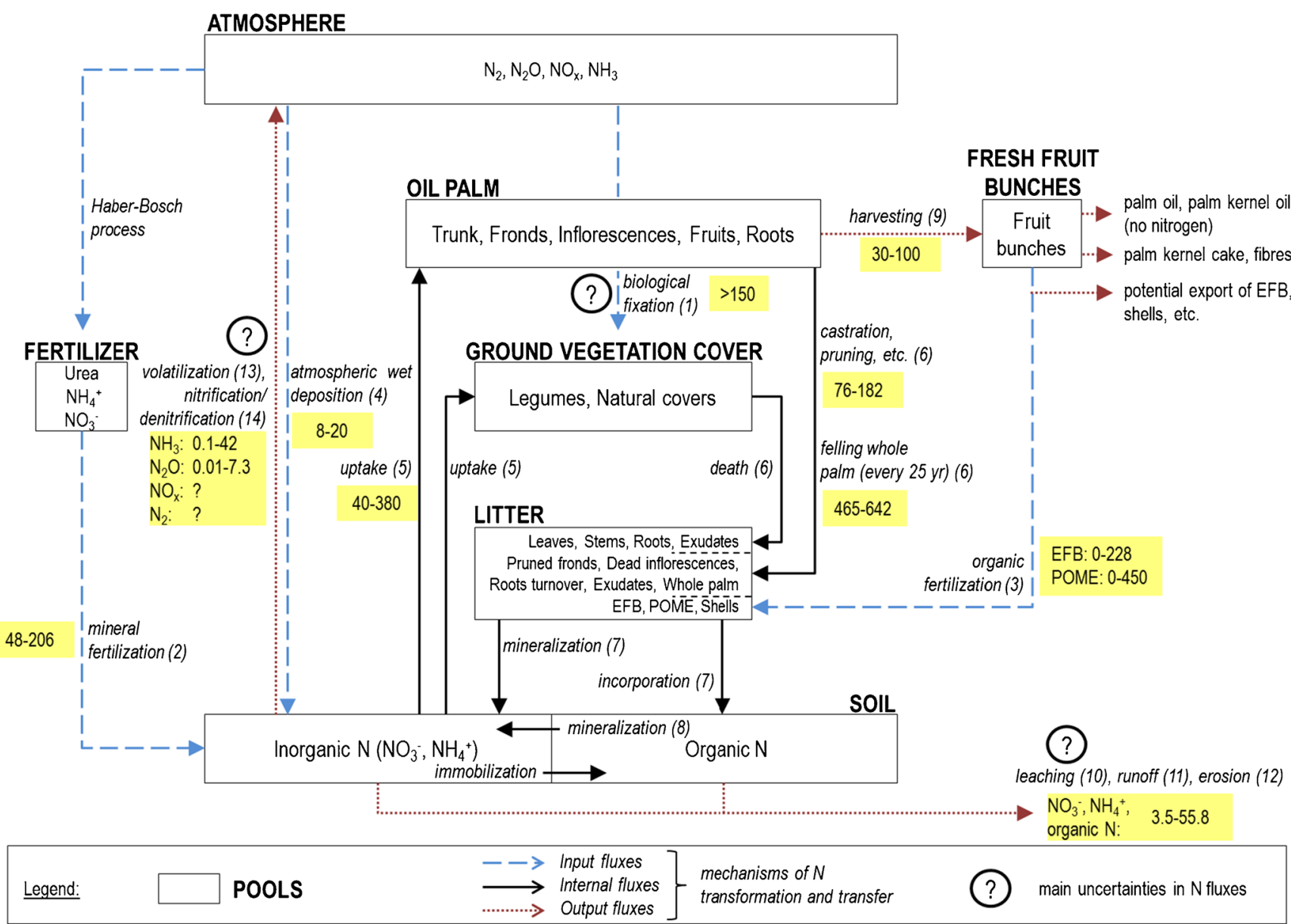

Fig. 2 The $\mathrm{N}$ budget in oil palm plantations, highlighting the main uncertainties. The largest annual $\mathrm{N}$ fluxes are mainly internal fluxes, and the most uncertain and least documented fluxes are $\mathrm{N}$ losses. The pools are represented by the rectangles and the main fluxes are represented by the arrows. The main uncertainties are highlighted with a question mark. Flux values are ranges given in $\mathrm{kg} \mathrm{N} \mathrm{ha}^{-1}$ year ${ }^{-1}$, and runoff, leaching, erosion, and volatilization of $\mathrm{NH}_{3}$ are estimated assuming an application of $100 \mathrm{~kg} \mathrm{~N} \mathrm{ha}^{-1}$ year $^{-1}$ of mineral $\mathrm{N}$ fertilizer (see Tables 1, 2, and 3 for sources). EFB empty fruit bunches, POME palm oil mill effluent 
leaves, stems, roots, and root exudates; and litter and soil $\mathrm{N}$ mineralization. Outputs from the system consist of export of the $\mathrm{N}$ in harvested products; volatilization of $\mathrm{NH}_{3}$; emissions of nitrate $\left(\mathrm{NO}_{3}{ }^{-}\right)$, ammonium $\left(\mathrm{NH}_{4}{ }^{+}\right)$, and organic $\mathrm{N}$ through leaching, runoff, and erosion; emissions of nitrous oxide $\left(\mathrm{N}_{2} \mathrm{O}\right), \mathrm{NO}_{x}$, and nitrogen gas $\left(\mathrm{N}_{2}\right)$ through nitrification and denitrification.

\section{$3 \mathbf{N}$ fluxes and variability in plantations: state-of-the-art}

We reviewed the knowledge available in the literature for all the input, internal, and output fluxes identified in Fig. 2.

\subsection{Inputs}

\subsubsection{Biological N fixation}

One input is the biological fixation of $\mathrm{N}$ from the atmosphere (flux no. 1 in Fig. 2), which is carried out by specific bacteria. Three types of fixation were mentioned in oil palm plantations: endophytic fixation inside the tissue of a palm colonized by bacteria (e.g., Azospirillum Reis et al. 2000), nonsymbiotic fixation which takes place in the litter or soil (e.g., Azobacter Aisueni 1987), and symbiotic fixation in the nodules of the roots of legumes (e.g. Rhizobia). Regarding endophytic fixation, Amir et al. (2001) reported an uptake of fixed $\mathrm{N}$ by palm seedlings in the greenhouse following inoculation with Azospirillum bacteria and Om et al. (2009) reported higher leaf protein and chlorophyll content in 280-day-old oil palm plants inoculated with Acetobacter. These results suggested that endophytic fixation is a flux of $\mathrm{N}$ input not negligible in oil palm systems, but other studies are necessary to obtain estimates of the magnitude of this flux.

The results regarding non-symbiotic fixation have so far been inconsistent or difficult to replicate in the field (Tinker and Nye 2000 in Corley and Tinker 2003). The magnitude of such inputs from non-symbiotic fixation might be similar to those in tropical forest ecosystems, which are on average 3.3$7.8 \mathrm{~kg} \mathrm{~N} \mathrm{ha}^{-1}$ year $^{-1}$, with a tendency to increase with temperature, soil moisture, and soil N scarcity (Reed et al. 2011).

Finally, for symbiotic $\mathrm{N}$ fixation, recent reviews were done on oil palm plantations (Giller and Fairhurst 2003; Ruiz and López 2014). Most of the quantifications of $\mathrm{N}$ fixation were made in Malaysia in the 1980s and 1990s, mostly with P. phaseoloides, and also M. bracteata, Calopogonium pubescens, and Calopogonium muconoides. Two main methods were reported: ${ }^{15} \mathrm{~N}$ isotope labeling and deduction from other fluxes with $\mathrm{N}$ budget approaches. The estimates of $\mathrm{N}$ fixed by legumes were very similar, with an average of $150 \mathrm{~kg} \mathrm{~N} \mathrm{ha}^{-1}$ year $^{-1}$ over the first 5 years (Broughton et al. 1977; Agamuthu and Broughton 1985; Zaharah et al. 1986).
A more recent work reported amounts of $\mathrm{N}$ biologically fixed of 0.3 to $34.2 \mathrm{~kg} \mathrm{~N} \mathrm{ha}^{-1}$ in legume covers under oil palm in shoots and litter, but more research would be needed to take into account fixed $\mathrm{N}$ in roots (Pipai 2014). However, Giller and Fairhurst (2003) noted that most estimates of fixation are likely to be underestimates, as they were all based on harvested legume plants without taking into account the biologically fixed $\mathrm{N}$ continually added to the litter through residue cycling.

\subsubsection{N fertilizers}

The other main $\mathrm{N}$ input is via the application of mineral (flux no. 2 in Fig. 2) and organic fertilizers (flux no. 3 in Fig. 2) such as empty fruit bunches and palm oil mill effluent. Several studies were done on fertilizer efficiency and several papers propose fertilizer recommendations, but few data are easily available on actual amounts of mineral and organic fertilizers applied in plantations. The amount of mineral fertilizer applied is very variable and ranges from 48 to $90 \mathrm{~kg} \mathrm{~N} \mathrm{ha}^{-1}$ year $^{-1}$ for immature palms (Henson 2004; Banabas 2007; Choo et al. 2011) and from 56 to $206 \mathrm{~kg} \mathrm{~N} \mathrm{ha}^{-1}$ year $^{-1}$ for mature palms (Foster 2003; FAO 2004; Carcasses 2004, unpublished data; Hansen 2007; United Plantations Berhad 2006; Wicke et al. 2008). It seems to be a common practice to reduce or even stop fertilizer application over the 2-3 years before felling (Choo et al. 2011), despite evidence that effects of $\mathrm{N}$ fertilizer on yield do not always persist from 1 year to the next (Caliman et al. 1994). The amount of fertilizer applied is adapted over time mainly on the basis of foliar $\mathrm{N}$ contents. This amount hence depends indirectly on the age of the palms, the soil and climate conditions, and the planting material which influences the potential yield.

The main types of $\mathrm{N}$ fertilizers used in oil palm are urea, containing $46 \%$ of $\mathrm{N}$, used everywhere; ammonium sulfate, $21 \%$ of $\mathrm{N}$, mainly used in Southeast Asia; and ammonium nitrate, $34 \%$ of N, used in Africa and South America (Corley and Tinker 2003; Goh and Härdter 2003; Banabas 2007). The main factors governing the choice of fertilizer type are the availability, e.g., related with legal framework; the cost per unit $\mathrm{N}$, including transport; and the local soil and climate conditions. The choice of the type of fertilizer is critical for $\mathrm{N}$ cycling processes and there might be tradeoffs between these selection factors. For instance, urea is less costly than other types, but it may produce high gaseous losses of $\mathrm{NH}_{3}$ in dry conditions (Goh et al. 2003). A common practice is to manually apply the fertilizers in an arc around the palm, using calibrated containers to deliver the required amount to each tree. For immature palms, it is applied close to the palm (Goh et al. 2003; Caliman et al. 2002). For mature palms, application practices vary. Applications can be made manually on the weeded circle, on the edge of the weeded circle, and even on the frond piles where more feeding roots are found and fewer 
losses may occur through runoff (Banabas 2007). Broadcast mechanical applications by tractors using spreaders with deflectors are now often used where labor is expensive or in short supply (Goh and Härdter 2003). Aerial application is also a developing practice but mainly used on peat soils and steeply sloping areas where mechanical application is not possible (Caliman et al. 2002). It is a common practice to split the application of $\mathrm{N}$ fertilizers in 2 or 3 per year, depending on soil type and rainfall distribution, to reduce the risk of nutrient losses. In immature palms, the splitting is usually increased to 4 to 5 applications per year because of the use of various fertilizers that cannot be systematically combined together (Goh et al. 2003; Banabas 2007). The optimal frequency is therefore a compromise between the need to meet nutrient demand, labor cost, risk of nutrient losses, and logistical issues for transport and storage (Goh et al. 2003). Fertilizers are normally applied after rainfall when the soil is wet, especially for urea to limit volatilization, but not during heavy rain periods to avoid losses through leaching, runoff, and erosion. However, there are situations where labor availability is also an important factor which influences the timing of applications (Banabas 2007).

Empty fruit bunches are commonly returned directly to the plantation from the mill after oil extraction, with an addition of supplementary mineral N (Corley and Tinker 2003). A plantation yielding $22 \mathrm{t}$ of fresh fruit bunches per hectare would produce empty fruit bunches for only about $10 \%$ of the mature plantation area. This estimate results from the assumptions that the weight of empty fruit bunches produced is 20 to $25 \%$ of the weight of fresh fruit bunches processed (Corley and Tinker 2003; Redshaw 2003) and that the application rate

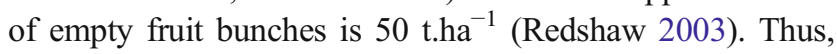
there is not enough empty fruit bunches for the whole plantation area and the preferential areas for spreading are those close to the mill and on relatively flat terrain, for reasons of cost and feasibility (Redshaw 2003). Soils with low carbon content are also favored because empty fruit bunch inputs increase their organic matter content (Carcasses 2004, unpublished data). This uneven distribution of empty fruit bunches creates a spatial heterogeneity of organic $\mathrm{N}$ input at the plantation scale.

Under immature palms, empty fruit bunches are applied in a single layer immediately around the palms. Annual applications of 15 to $60 \mathrm{tha}^{-1}$ are common, and even larger rates of $80 \mathrm{t} \mathrm{ha}^{-1}$ may be used on an 18-month or 2-year cycle (Redshaw 2003). Under mature palms, empty fruit bunches are usually spread in the harvest pathway or in some cases in between palms in the row in order to keep the weeded circle easily accessible for harvest. Application rates of 30 to $60 \mathrm{t} \mathrm{ha}^{-1}$ are common (Banabas 2007; Redshaw 2003). The empty fruit bunches contain from 0.26 to $0.38 \% \mathrm{~N}$ in fresh matter (0.65 to $0.94 \%$ in dry matter) (Corley et al. 1971; Singh et al. 1982; Singh 1999; Gurmit et al. 1990, 1999;
Caliman et al. 2001b). Empty fruit bunch application rates vary widely. Hence, the associated inputs of $\mathrm{N}$ are also very variable ranging from 39 to $228 \mathrm{~kg} \mathrm{~N} \mathrm{ha}^{-1}$ year $^{-1}$ under immature palms and from 78 to $228 \mathrm{~kg} \mathrm{~N} \mathrm{ha}^{-1}$ year ${ }^{-1}$ under mature palms. In addition to direct application to fields, empty fruit bunches are also used to produce compost, with the advantage of reducing the volume of biomass to transport for field application. Empty fruit bunches are commonly mixed with palm oil mill effluent or urea, and the final $\mathrm{N}$ content of compost ranges from 1.5 to $2.7 \%$ in dry matter (Lord et al. 2002; Siregar et al. 2002; Schuchardt et al. 2002 in Redshaw 2003).

Palm oil mill effluent is often spread in the plantations following treatment in ponds. The treatment ponds are designed to decrease biological oxygen demand. Depending on the treatment, palm oil mill effluent contains from 0.92 to $1.2 \mathrm{~kg} \mathrm{~N} \mathrm{t}^{-1}$ (Redshaw 2003; Corley and Tinker 2003; Corcodel et al. 2003; Schmidt 2007). The rate and frequency of application depend mainly on the maximal rate legally allowed and on the application system, but one reported application rate was about $375 \mathrm{t} \mathrm{ha}^{-1}$ year $^{-1}$ split in three applications (Carcasses 2004, unpublished data). At that rate, the inputs of $\mathrm{N}$ generated are rather high at approximately 345 to $450 \mathrm{~kg} \mathrm{~N} \mathrm{ha}^{-1}$ year $^{-1}$. As for the empty fruit bunches, palm oil mill effluent is spread onto only a small portion of the whole plantation area, dictated by the application system and the distance between the mill and the field. Several application systems are used, such as gravity flow, pipe irrigation with a pump, or application by a tractor with a tanker (Lim 1999; Redshaw 2003).

\subsection{3 $\mathrm{N}$ depositions}

The $\mathrm{N}$ inputs that are the most difficult to quantify and least well known are those from atmospheric (flux no. 4 in Fig. 2) and sediment depositions. At a global scale, production of $\mathrm{Nr}$, such as $\mathrm{NH}_{3}$ and $\mathrm{NO}_{x}$, by lightning and volcanic activity is small (Galloway et al. 1995; Mather et al. 2004), but it may be significant in some oil palm-growing regions. To our knowledge, only measurements of wet deposition have been done in oil palm systems, i.e., for $\mathrm{N}$ contained in rain water (possibly including aerosols). Depositions were reported to range from 14.6 to $20 \mathrm{~kg} \mathrm{~N} \mathrm{ha}^{-1}$ year $^{-1}$ in Malaysia (Agamuthu and Broughton 1985; Chew et al. 1999) and were measured at $8 \mathrm{~kg} \mathrm{~N} \mathrm{ha}^{-1}$ year $^{-1}$ in Brazil (Trebs et al. 2006).

$\mathrm{N}$ inputs also result from the deposition of eroded particles of soil coming from upslope of the system studied. This flux concerns mainly lowland areas where the eroded soil from upper areas accumulates and hence it depends on the local topography. To our knowledge, no specific measurements of $\mathrm{N}$ deposition have been done to estimate this input flux in palm plantations. Finally, input of $\mathrm{N}$ to ecosystems from weathering of rocks is usually considered to be negligible. However, it is possible that it constitutes a significant input 
if the geology consists of fine sedimentary rocks (Holloway and Dahlgren 2002), given the intense weathering conditions of oil palm-growing regions.

In summary, $\mathrm{N}$ inputs were estimated, in $\mathrm{kg} \mathrm{N} \mathrm{ha}^{-1}$ year $^{-1}$, at 150, 0-206, 0-450, 8-20, for biological $\mathrm{N}$ fixation, mineral fertilizer, organic fertilizers, and atmospheric deposition, respectively. The results and references are synthesized in Table 1.

\subsection{Internal fluxes}

\subsubsection{N uptake}

A major internal flux is the $\mathrm{N}$ uptake from soil by palms, legume cover crops, and other plants, mainly as inorganic $\mathrm{N}$ $\left(\mathrm{NH}_{4}{ }^{+}\right.$and $\left.\mathrm{NO}_{3}{ }^{-}\right)$(flux no. 5 in Fig. 2). Uptake by plants other than palms and legumes may be significant because it is known to compete with palms and affect fresh fruit bunches production (Corley and Tinker 2003). However, to our knowledge, no measurements of such uptake terms are available. For the legume cover, Agamuthu and Broughton (1985) estimated that $149 \mathrm{~kg} \mathrm{~N} \mathrm{ha}^{-1}$ year $^{-1}$ was taken up from the soil over the first 3 years of the oil palm cycle. For palms, two main reviews have reported estimates of N uptake (Xaviar 2000; Goh and Härdter 2003), with most of the work done on Dura palms in
Malaysia and Nigeria between the 1960s and 1990s. Other work was done more recently on Tenera palms in Sumatra (Foster and Parabowo 2003). In all cases, estimates reported are not direct measurements of $\mathrm{N}$ uptake by roots but indirect estimates inferred from a nutrient budget approach. Thus, over the whole growth cycle, the net $\mathrm{N}$ uptake is considered to be equal to the $\mathrm{N}$ immobilized in the palm, above- and belowground biomass; the $\mathrm{N}$ released in palm residues such as pruned fronds, removed inflorescences, frond bases, dead roots; and the $\mathrm{N}$ exported in harvested bunches.

The results reported by Xaviar (2000) and Goh and Härdter (2003) showed that uptake rate mainly depends on the age of the palms, with estimates of $40 \mathrm{~kg} \mathrm{~N} \mathrm{ha}^{-1}$ year $^{-1}$ for 0 to 3year-old palms (Tan 1976, 1977) and ranging from 114 to $267 \mathrm{~kg} \mathrm{~N} \mathrm{ha}^{-1}$ year $^{-1}$ for 3 to 9-year-old palms (Ng 1977; Pushparajah and Chew 1998; Henson 1999; Ng et al. 1999; Ng and Thamboo 1967; Ng et al. 1968; Tan 1976, 1977). However, recent work has resulted in considerably higher estimates of uptake by Tenera palms, up to $272 \mathrm{~kg} \mathrm{~N} \mathrm{ha}^{-1}$ year $^{-1}$ in 10-year-old palms and even $380 \mathrm{~kg} \mathrm{~N}^{-1}$ year $^{-1}$ in adult palms (Foster and Parabowo 2003). Both studies considered only above-ground biomass in the budgets. This difference could be explained by the higher yields now obtained with current genotypes (Goh and Härdter 2003). Recent measurements in trials in Indonesia showed uptake rates by above-

Table 1 Summary of $\mathrm{N}$ inputs estimates from the reviewed experimental data

\begin{tabular}{|c|c|c|c|c|}
\hline Fluxes & $\begin{array}{l}\text { Estimates } \\
\mathrm{kg} \mathrm{N}^{-1} \text { year }^{-1} \\
\text { or } \% \text { of } \mathrm{N} \text { applied }\end{array}$ & $\begin{array}{l}\text { Variability } \\
\text { Ratio } \max / \min \end{array}$ & $\begin{array}{l}\text { Main controls } \\
\text { identified in literature }\end{array}$ & References \\
\hline \multirow[t]{3}{*}{ Biological $\mathrm{N}$ fixation } & Endophytic: needs confirmation & - & - & (Reis et al. 2000); (Amir et al. 2001) \\
\hline & Non-symbiotic: $3.3-7.8$ & 2.4 & $\begin{array}{l}\text { Increasing with temperature, } \\
\text { soil moisture, soil N scarcity }\end{array}$ & (Reed et al. 2011) (tropical forest) \\
\hline & $\begin{array}{l}\text { Symbiotic: }>150 \text { (average over } \\
\text { the first } 5 \text { years) }\end{array}$ & 1 & $\mathrm{~N}$ content in soils & $\begin{array}{l}\text { (Giller and Fairhurst 2003) }{ }^{\mathrm{a}} \text {; (Ruiz and } \\
\text { López 2014) }{ }^{\mathrm{a}} \text { (Broughton et al. } \\
\text { 1977); (Agamuthu and Broughton } \\
\text { 1985); (Zaharah et al. 1986) }\end{array}$ \\
\hline \multirow[t]{3}{*}{ Fertilizer application } & $\begin{array}{l}\text { Mineral: } 48-90 \text { in } 4-5 \\
\text { applications (immature) } \\
56-206 \text { in } 2-3 \text { applications } \\
\text { (mature) } \\
0 \text { (2-3 years before replanting) }\end{array}$ & 4.3 & $\begin{array}{l}\mathrm{N} \text { foliar content (indirect factors: } \\
\text { age, soil and climate, } \\
\text { planting material) }\end{array}$ & $\begin{array}{l}\text { (Henson 2004) (Banabas 2007) } \\
\text { (Choo et al. 2011) (Foster 2003) } \\
\text { (FAO 2004) (Carcasses 2004, } \\
\text { unpublished data) (Hansen 2005) } \\
\text { (United Plantations Berhad 2006) } \\
\text { (Wicke et al. 2008) }\end{array}$ \\
\hline & $\begin{array}{l}\text { Empty fruit bunches: } \\
0 \text { in most fields } \\
39-228 \text { (immature) } \\
78-228 \text { (mature) }\end{array}$ & 5.8 & $\begin{array}{l}\text { Age, distance to the mill, slope, } \\
\text { soil fertility }\end{array}$ & (Banabas 2007) (Redshaw 2003) \\
\hline & $\begin{array}{l}\text { POME: } 0 \text { in some plots } \\
345-450\end{array}$ & $-\overline{1.3}$ & Distance to the mill, laws & (Carcasses 2004, unpublished data) \\
\hline $\begin{array}{r}\text { Atmospheric } \\
\text { deposition }\end{array}$ & $\begin{array}{l}8 \text { in Brazil } \\
14.6-20 \text { in Malaysia }\end{array}$ & 2.5 & $\begin{array}{l}\text { Rainfalls, proximity of industries } \\
\text { and volcanic activity }\end{array}$ & $\begin{array}{l}\text { (Agamuthu and Broughton 1985) } \\
\text { (Chew et al. 1999) (Trebs et al. 2006) }\end{array}$ \\
\hline Sediment deposition & No data available & & & \\
\hline Weathering of rocks & No data available & & & \\
\hline
\end{tabular}

${ }^{a}$ Review articles that may be helpful for readers to have a quick overview of each flux 
ground biomass ranging from about 221 to $272 \mathrm{~kg} \mathrm{~N} \mathrm{ha}^{-1}$ year $^{-1}$, depending on the planting material. In addition to genotype, variability of uptake seems to be linked with soil and climate conditions. For example, uptake was estimated at $149 \mathrm{~kg} \mathrm{~N}^{-1}$ year $^{-1}$ in Nigerian conditions with a production of $9.7 \mathrm{t}$ of fresh fruit bunches ha ${ }^{-1}$ year $^{-1}$ (Tinker and Smilde 1963) and at $191 \mathrm{~kg} \mathrm{~N} \mathrm{ha}^{-1}$ year $^{-1}$ in Malaysian conditions with a production of $24 \mathrm{t}$ of fresh fruit bunches ha ${ }^{-1}$ year $^{-1}$ (Ng and Thamboo 1967; Ng et al. 1968).

\subsection{2 $\mathrm{N}$ from plant residues to the litter}

Another major internal flux is the $\mathrm{N}$ contained in plant residues, which goes from the plants to the litter (flux no. 6 in Fig. 2). Residues come from the palms, legume cover crops, and other vegetation. For plants other than palms and legumes, to our knowledge no data is available. For legume cover, Agamuthu and Broughton (1985) estimated an amount of $123 \mathrm{~kg} \mathrm{~N} \mathrm{ha}^{-1}$ year $^{-1}$ going from the living plants to the litter over the first 3 years under oil palm and Pushparajah (1981) estimated an amount of about $120-160 \mathrm{~kg} \mathrm{~N} \mathrm{ha}^{-1}$ year $^{-1}$ over the first to the third years and less than $40 \mathrm{~kg} \mathrm{~N} \mathrm{ha}^{-1}$ year $^{-1}$ over the fourth to the seventh years under rubber trees. In both cases, root turnover was not taken into account. For palms, several residues are distinguished: those produced throughout the crop cycle, mostly in the mature phase such as pruned fronds, removed inflorescences, frond bases, root exudates, and dead roots and those produced only once before replanting, i.e., the whole palm when it is felled.

For pruned fronds, the flux of $\mathrm{N}$ depends on the quantity of fronds pruned and their $\mathrm{N}$ content. Frond production rate stabilizes after $8-12$ years at about 20-24 fronds year ${ }^{-1}$ (Corley and Tinker 2003). Several publications estimated the annual flux of $\mathrm{N}$ going to the litter, with values ranging from 67 to $131 \mathrm{~kg} \mathrm{~N} \mathrm{ha}^{-1}$ year $^{-1}$ (Redshaw 2003; Carcasses 2004, unpublished data; Turner and Gillbanks 2003; Schmidt 2007). Therefore, this flux is uncertain and the reasons for the variability are not well defined; they may depend on the soil, climate, and planting material which influence frond production and frond weight and on the methods of measurement of $\mathrm{N}$ content. For male inflorescences, the flux of $\mathrm{N}$ going to the litter has been ignored in most $\mathrm{N}$ cycling studies. We found only two estimates, being 6 and $11.2 \mathrm{~kg} \mathrm{~N}^{-1}$ year $^{-1}$ (Carcasses 2004, unpublished data; Turner and Gillbanks 2003, respectively). These estimates suggest that this flux is lower than the uncertainty of the concomitant $\mathrm{N}$ flux via pruned fronds. For frond bases, which rot and fall naturally from the trunk, the only estimate we found was of $3 \mathrm{~kg} \mathrm{~N} \mathrm{ha}^{-1}$ year $^{-1}$ going to the litter (Carcasses 2004, unpublished data).

For root exudates and transfers into the soil via Mycorrhizae, no estimate of $\mathrm{N}$ flux is available to our knowledge. Roots themselves are continuously dying and being replaced by new ones. This death of roots constitutes a flux of $\mathrm{N}$ going from the palm to the litter pool and depends on the rate of root turnover and on the $\mathrm{N}$ content of roots when they die. Root turnover is very difficult to measure. Corley and Tinker (2003) reviewed several methods to estimate it such as deduction from measurements of soil carbon balance or measurements of the growth of roots after extracting soil cores and refilling the holes with root-free soil. Estimates of average turnover ranged from 1.03 to $11.5 \mathrm{t}$ of dry matter $\mathrm{ha}^{-1}$ year $^{-1}$ for adult palms (Dufrêne 1989; Lamade et al. 1996; Henson and Chai 1997; Jourdan et al. 2003), and turnover was reported to be zero for 3-4-year-old palms (Henson and Chai 1997). Thus, with an average root $\mathrm{N}$ content of $0.32 \%$ of dry matter measured by $\mathrm{Ng}$ et al. (1968) in 8-15-year-old palms in Malaysia, the average $\mathrm{N}$ flux from root turnover would range from 3.3 to $36.8 \mathrm{~kg} \mathrm{~N}^{-1}$ year $^{-1}$. (Carcasses 2004, unpublished data) also proposed the value of $7.5 \mathrm{~kg} \mathrm{~N} \mathrm{ha}^{-1}$ year $^{-1}$ based on data from Henson and Chai (1997). Therefore, this flux is highly uncertain. Moreover, Corley and Tinker (2003) noted that root turnover measured in Malaysia was much lower than that in Africa, which could be explained by the death of a larger part of the root system in Africa during the annual dry season (Forde 1972).

Finally, the estimate of the $\mathrm{N}$ contained in the felled palms must take into account above- and below-ground biomasses. Several publications estimated the weight of dry matter of above-ground biomass of old palms at felling and the $\mathrm{N}$ content of their different tissues, i.e., trunk, fronds, inflorescences, and frond bases (see for e.g., Corley and Tinker 2003). Some of them reviewed available data to estimate the total $\mathrm{N}$ content of palms at felling and reported values ranging from 400 to $577 \mathrm{~kg} \mathrm{~N} \mathrm{ha}^{-1}$ (Khalid et al. 1999a; Redshaw 2003; Schmidt 2007). Fewer studies estimated the below-ground dry matter of palms, but Khalid et al. (1999b) reported a value of $65 \mathrm{~kg} \mathrm{~N} \mathrm{ha}{ }^{-1}$. Therefore, the total $\mathrm{N}$ contained in palms at felling and going to the litter has been estimated at 465 to $642 \mathrm{~kg} \mathrm{~N} \mathrm{ha}^{-1}$.

\subsection{3 $N$ from the litter to the soil}

Another important internal flux is the mineralization or incorporation of $\mathrm{N}$ from the litter to the soil (flux no. 7 in Fig. 2). The litter is composed mostly of plant residues but also contains active microorganisms and fauna. To our knowledge, no data is available regarding the decomposition of residues from plants other than oil palm or legumes in the oil palm system.

For legume litter decomposition, Chiu (2004) measured losses of about $70 \%$ of dry matter after about 2-3 months in leaves and stems of $P$. phaseoloides and M. bracteata. But the net $\mathrm{N}$ release follows a slower dynamic due to the immobilization of the $\mathrm{N}$ by the microbial fauna and flora involved in decomposition and the partial uptake of the $\mathrm{N}$ released by growing legumes. For instance, Vesterager et al. (1995) measured in a pot experiment with $P$. phaseoloides a 
net release of about $25 \%$ of the $\mathrm{N}$ of the legume litter after 2 months, using a ${ }^{15} \mathrm{~N}$ labeling technique. In an oil palm field, Turner and Gillbanks (2003) reported that net N release from legume litter occurred between the 24th and the 30th months after planting.

For palm residues, no data was found for frond bases. For pruned fronds and felled and chipped trunks, Khalid et al. (2000) observed a loss of $50 \%$ of dry matter after 6-8 months and a total decomposition after 12-18 months. For roots, Khalid et al. (2000) observed a loss of $50 \%$ of dry matter after 10 months and a total decomposition after about 25 months. These decomposition rates were considered as approximately linear by Khalid et al. (2000), but Moradi et al. (2014) observed an exponential decrease with a faster decomposition over the first 5 months. Khalid et al. (2000) identified rainfall distribution as the main climatic factor controlling the rate of decomposition and observed that shredded residues decompose faster than un-shredded residues. For empty fruit bunches, when mineral $\mathrm{N}$ fertilizer was also added, losses of $50 \%$ of dry matter were reported after 2-3 months (Turner and Gillbanks 2003; Lim and Zaharah 2000; Rosenani and Hoe 1996), and total decomposition occurred within 6 to 12 months (Rosenani and Hoe 1996; Henson 2004; Caliman et al. 2001b). The decrease followed an exponential dynamic (Lim and Zaharah 2000); the decomposition was faster when empty fruit bunches were applied in one layer than in two layers (Lim and Zaharah 2000) and was slower without addition of mineral N (Caliman et al. 2001b). However, for all of these palm residues, the dynamics of $\mathrm{N}$ release is more complex than the dynamics of decomposition due to immobilization by the microbial fauna and flora involved in decomposition. For instance, for trunks, Kee (2004) observed that the net release of $\mathrm{N}$ occurred only 12 months after felling. For empty fruit bunches, Zaharah and Lim (2000) observed a complete $\mathrm{N}$ immobilization over their experimental period of about 8 months, and Caliman et al. (2001b) reported a $\mathrm{N}$ release of only $50 \%$ at about 6 months, without adding mineral $\mathrm{N}$.

The last internal flux considered is the mineralization of soil organic N (flux no. 8 in Fig. 2). Only few data are available, and they involve various soil depths, which hampers comparison. Schroth et al. (2000) estimated the net mineralization in the top $10 \mathrm{~cm}$ of a central Amazonian upland soil at approximately $157 \mathrm{~kg} \mathrm{~N} \mathrm{ha}^{-1}$ year $^{-1}$ after 15 years of oil palm production without any $\mathrm{N}$ fertilizer inputs. Khalid et al. (1999c) estimated the $\mathrm{N}$ mineralization after replanting in Malaysia at about $312 \mathrm{~kg} \mathrm{~N}^{-1}$ year $^{-1}$ in fields without residues from the previous cycle except dead roots and at about $421 \mathrm{~kg} \mathrm{~N} \mathrm{ha}^{-1}$ year $^{-1}$ in fields where the palm residues from the previous cycle were left on the soil. Finally, Allen et al. (2015) estimated the $\mathrm{N}$ mineralization in the top $5 \mathrm{~cm}$ of soil in Sumatra at about $920 \mathrm{~kg} \mathrm{~N} \mathrm{ha}^{-1}$ year $^{-1}$ in loam Acrisol and up to $1528 \mathrm{~kg} \mathrm{~N} \mathrm{ha}^{-1}$ year $^{-1}$ in clay Acrisol. However, those measurements were done under more than 7-year-old oil palms established after logging, clearing, and burning of either forest or jungle rubber.

In summary, internal fluxes were estimated, in $\mathrm{kg}$ $\mathrm{N} \mathrm{ha}^{-1}$ year $^{-1}$, at $149,40-380,0-160,76-182$, and 1571528 , for legume uptake, oil palm uptake, legume residues decomposition, oil palm residues decomposition, and soil $\mathrm{N}$ mineralization, and 465-642 for the decomposition of the felled palm at the end of the cycle. The results and references are synthesized in Table 2 .

\subsection{Outputs}

\subsubsection{N exported in fresh fruit bunches}

A major output is the $\mathrm{N}$ contained in fresh fruit bunches and exported during harvest (flux no. 9 in Fig. 2). The $\mathrm{N}$ content of the fresh fruit bunches was reported to be around 2.89$2.94 \mathrm{~kg} \mathrm{~N} \mathrm{t}^{-1}$ of fresh fruit bunches in fresh weight $(\mathrm{Ng}$ and Thamboo 1967; Ng et al. 1968; Hartley 1988; in Corley and Tinker 2003 and Goh et al. 2003), but some higher values were also reported, as much as $6.4 \mathrm{~kg} \mathrm{~N} \mathrm{t}^{-1}$ fresh fruit bunches (Ng et al. 1999). In general, the fresh fruit bunches production starts at about 2-3 years of age and increases rapidly until leveling off at yields around 10-34 $\mathrm{t}$ of fresh fruit bunches ha ${ }^{-1}$ year $^{-1}$ after the tenth year (Tinker 1976; Corley and Tinker 2003). Some very high yields were also reported at around $40 \mathrm{t}$ of fresh fruit bunches $\mathrm{ha}^{-1}$ year $^{-1}$ (Kee et al. 1998). Thus, the yield depends on the age of the palm, but it also differs with the type of planting material, soil, and climate conditions. For instance, yields were reported to be lower in Nigeria (9.6 $\mathrm{t} \mathrm{FBB} \mathrm{ha}^{-1} \mathrm{year}^{-1}$ ) than in Malaysia (24 t FBB ha ${ }^{-1}$ year $^{-1}$ ) (Tinker 1976). Therefore, for adult palms more than 10 years old producing 10 to $34 \mathrm{t}$ of fresh fruit bunches $\mathrm{ha}^{-1}$ year $^{-1}$, we deduced an export of $\mathrm{N}$ through harvest of around 30 to $100 \mathrm{~kg} \mathrm{~N} \mathrm{ha}^{-1}$ year $^{-1}$, consistent with other estimates done for Nigeria (Tinker and Smilde 1963) and Malaysia (Ng and Thamboo 1967; Ng et al. 1968).

\subsubsection{N leaching}

Soluble forms of $\mathrm{N}\left(\mathrm{NO}_{3}{ }^{-}\right.$and $\left.\mathrm{NH}_{4}{ }^{+}\right)$can be lost by leaching out of the root zone (flux no. 10 in Fig. 2). Tropical soils may have significant anion exchange capacity and thus retain $\mathrm{NO}_{3}{ }^{-}$(Rasiah et al. 2003), but such anion exchange capacity is usually not significant within the root zone. As most of the oil palm root activity is located within $1 \mathrm{~m}$ depth (Ng et al. 2003; Corley and Tinker 2003) and rainfalls are high in the tropics, this suggests a high potential risk of nutrient leaching under oil palm.

Many studies investigated the losses of $\mathrm{N}$ through leaching in plantations and were reviewed by Corley and Tinker (2003) and Comte et al. (2012). Most of the research was done in the 
Table 2 Summary of $\mathrm{N}$ internal inputs estimates from the reviewed experimental data

\begin{tabular}{|c|c|c|c|c|}
\hline Fluxes & $\begin{array}{l}\text { Estimates kg N ha }{ }^{-1} \text { year }^{-1} \\
\text { or } \% \text { of } \mathrm{N} \text { applied }\end{array}$ & $\begin{array}{l}\text { Variability } \\
\text { Ratio } \mathrm{max} / \mathrm{min}\end{array}$ & $\begin{array}{l}\text { Main controls } \\
\text { identified in literature }\end{array}$ & References \\
\hline Uptake by other plants & No data available & & & \\
\hline Uptake by legume cover & 149 (1-3 years) & - & - & (Agamuthu and Broughton 1985) \\
\hline Uptake by palms & $\begin{array}{l}40 \text { (palms of } 0-3 \text { years) } \\
114-380 \text { (palms of more } \\
\text { than } 3 \text { years) }\end{array}$ & 9.5 & Age, soil and climate, genotype & $\begin{array}{l}\text { (Xaviar 2000) }{ }^{\mathrm{a}} \text {; (Goh et al. 2003) } \\
\text { (Tan 1976) (Tan 1977) (Ng 1977) } \\
\text { (Pushparajah and Chew 1998) } \\
\text { (Henson 1999); (Ng et al. 1999); } \\
\text { (Ng and Thamboo 1967); (Ng et al. } \\
\text { 1968); (Foster and Parabowo 2003) }\end{array}$ \\
\hline \multirow[t]{8}{*}{$\begin{array}{l}\text { Transfer to the litter } \\
\text { through plant residues }\end{array}$} & $\begin{array}{l}\text { Legume residues: } \\
120-160 \text { ( } 1-3 \text { years }) \\
<40 \text { ( } 4-7 \text { years })\end{array}$ & 1.3 & - & $\begin{array}{l}\text { (Agamuthu and Broughton 1985); } \\
\text { (Pushparajah 1981) }\end{array}$ \\
\hline & $\begin{array}{l}\text { Pruned fronds: } \\
67-131\end{array}$ & 2.1 & $\begin{array}{l}\text { Soil and climate, } \\
\text { planting material }\end{array}$ & $\begin{array}{l}\text { (Corley and Tinker 2003); } \\
\text { (Redshaw 2003); (Carcasses 2004, } \\
\text { unpublished data); (Turner and } \\
\text { Gillbanks 2003); (Schmidt 2007) }\end{array}$ \\
\hline & $\begin{array}{l}\text { Male inflorescences: } \\
6-11.2\end{array}$ & 1.8 & - & $\begin{array}{l}\text { (Carcasses 2004, unpublished data); } \\
\text { (Turner and Gillbanks 2003) }\end{array}$ \\
\hline & Frond bases: 3 & - & - & (Carcasses 2004, unpublished data) \\
\hline & Root exudates & \multicolumn{3}{|l|}{ No data available } \\
\hline & $\begin{array}{l}\text { Roots turnover: } \\
0 \text { (palms of } 3-4 \text { years) } \\
3.3-36.8 \text { (adult palms) }\end{array}$ & 11.2 & $\begin{array}{l}\text { Age, climate (the dry season } \\
\text { increases roots death } \\
\text { and turnover) }\end{array}$ & $\begin{array}{l}\text { (Corley and Tinker 2003) }^{\mathrm{a}} \\
\text { (Dufrêne 1989) (Lamade et al. 1996); } \\
\text { (Henson and Chai 1997); } \\
\text { (Jourdan et al. 2003); } \\
\text { (Carcasses 2004, unpublished data) }\end{array}$ \\
\hline & $\begin{array}{l}\text { Whole palm: } \\
400-577 \text { (above-ground) }\end{array}$ & 1.4 & - & $\begin{array}{l}\text { Khalid et al. 1999a, b; } \\
\text { (Redshaw 2003);(Schmidt 2007) }\end{array}$ \\
\hline & 65 (below-ground) & - & & \\
\hline \multirow[t]{5}{*}{ Litter $\mathrm{N}$ mineralization } & $\begin{array}{l}\text { Legume: } \\
\text { Net release of } \mathrm{N} \text { between } \\
\quad \text { the 24-30th months }\end{array}$ & - & - & (Turner and Gillbanks 2003) \\
\hline & $\begin{array}{l}\text { Sawn trunks: } \\
\text { Net release of } N \text { between } \\
\quad 12-18 \text { months }\end{array}$ & - & Rainfall distribution, shredding & (Khalid et al. 2000) \\
\hline & $\begin{array}{l}\text { Pruned fronds: } \\
\text { Total decomposition after } \\
\quad 12-18 \text { months }\end{array}$ & - & Rainfall distribution & (Khalid et al. 2000) \\
\hline & $\begin{array}{l}\text { Roots: } \\
\text { Total decomposition } \\
\quad \text { after } 25 \text { months }\end{array}$ & - & Rainfall distribution & (Khalid et al. 2000) \\
\hline & $\begin{array}{l}\text { Empty fruit bunches: } \\
\text { Total decomposition } \\
\text { after 6-12 months }\end{array}$ & - & $\begin{array}{l}\text { Number of layers, adding } \\
\text { mineral fertilizer }\end{array}$ & $\begin{array}{l}\text { (Rosenani and Hoe 1996) } \\
\text { (Henson 2004) } \\
\text { (Caliman et al. 2001b) }\end{array}$ \\
\hline Soil N mineralization & $157-1528$ & 9.7 & $\begin{array}{l}\text { Fertilizer application, presence } \\
\text { of residues, soil type }\end{array}$ & $\begin{array}{l}\text { (Schroth et al. 2000) } \\
\quad \text { (Khalid et al. 1999c) } \\
\text { (Allen et al. 2015) }\end{array}$ \\
\hline
\end{tabular}

${ }^{\text {a }}$ Review articles that may be helpful for readers to have a quick overview of each flux

1980s and 1990s in Malaysia. Different plot-scale methods were used, such as lysimetric measurements, suction cup, and soil core sampling, and some studies were done at a larger scale with catchment sampling (e.g., Ah Tung et al. 2009). The age of the palms is one of the main control variables which can be identified. The measured values varied over a wide range, from 1 to $34 \%$ of $\mathrm{N}$ applied (Omoti et al. 1983; Foong et al. 1983;
Chang and Abas 1986; Foong 1993; Ng et al. 1999; Henson 1999; Ah Tung et al. 2009). Of the fertilizer N applied, 10.9 to $26.5 \%$ was lost with palms less than 4 years old (Foong et al. 1983; Foong 1993) versus 1 to $4.8 \%$ for palms older than 5 years (Foong et al. 1983; Foong 1993; Ah Tung et al. 2009). Only Omoti et al. (1983) reported losses of $34 \%$ of N applied in Nigeria for palms from 4 to 22 years old. 
In the conditions studied and despite very large variability, measurements hence showed that high losses through leaching are restricted to the first years of the palms, when the root systems are not fully developed and $\mathrm{N}$ inputs from decomposing plant residues are large. Moreover, fertilizer placement may have a significant effect on leaching because of the spatial variability of application rate, rainfall as through fall and stem flow, and N uptake (Banabas et al. 2008; Schroth et al. 2000). However, there is little information about the spatial distribution of $\mathrm{NO}_{3}^{-}$leaching within the plantation.

\subsection{3 $\mathrm{N}$ losses through runoff and erosion}

$\mathrm{N}$ can also be lost through runoff (flux no. 11 in Fig. 2) and erosion (flux no. 12 in Fig. 2) as a solute $\left(\mathrm{NO}_{3}{ }^{-}\right.$and $\mathrm{NH}_{4}{ }^{+}$) or as eroded particles of soil containing N. Corley and Tinker (2003) and Comte et al. (2012) reviewed measurements of N losses through runoff and erosion from oil palm plantations. Research was done in Malaysia from the 1970s to the 1990s (Maena et al. 1979; Kee and Chew 1996) and more recently in Papua New Guinea (Banabas et al. 2008) and Sumatra (Ribka 2014). The main variables studied were the effect of soil type, slope, and spatial heterogeneity resulting from management practices, such as soil cover management. The variability of reported values is less than for leaching, ranging from 2 to $15.6 \%$ of $\mathrm{N}$ applied lost through runoff, and from 0.5 to $6.2 \%$ of $\mathrm{N}$ applied lost through erosion (Maena et al. 1979; Kee and Chew 1996). Spatial heterogeneity of soil cover seems to have an important effect on losses. Maena et al. (1979) reported losses through runoff of $2 \%$ of $\mathrm{N}$ applied in frond piles, but $16 \%$ of that applied in the harvest pathway. Ribka (2014) showed that 10 to $37 \mathrm{t}$ of soil ha ${ }^{-1}$ year $^{-1}$ were lost through erosion of bare soil, depending on slope, but this reduced to 2 to $4 \mathrm{t}$ of soil $\mathrm{ha}^{-1}$ year $^{-1}$ with a standard vegetation cover and the same slopes.

These results indicated that soil cover has a significant effect on both runoff and erosion under oil palm. However, data is lacking concerning the transition between the felling of palms and the early development of young palms when the soil is not yet covered by the legume. Finally, it can be noted that in a given situation, there is a balance between runoff/ erosion losses and leaching losses, in which soil permeability plays an important role. For instance, in Papua New Guinea, Banabas et al. 2008 estimated losses through leaching at about $37-103 \mathrm{~kg} \mathrm{~N} \mathrm{ha}^{-1}$ year $^{-1}$ and negligible runoff, even with a high rainfall of $3000 \mathrm{~mm}^{-1} \mathrm{ear}^{-1}$. The authors suggested that the high permeability of volcanic ash soils could favor leaching over runoff.

\subsection{4 $N$ gaseous losses}

A potentially important gaseous output is the volatilization of $\mathrm{NH}_{3}$ (flux no. 13 in Fig. 2), which can occur directly from the leaves and from soil after fertilizer application, especially urea. Regarding emissions from palm fronds and other vegetation in the system, to our knowledge, no measurements have been reported. For emissions from soil following fertilizer application, several studies were done into urea efficiency under oil palm (e.g. Mohammed et al., 1991) but only a few measured $\mathrm{NH}_{3}$ volatilization. Most of them were done in Malaysia between the 1960s and the 1980s, and they often compared urea and ammonium sulfate, the most commonly used fertilizers in oil palm plantations. Two studies were done in Malaysia using different fertilizer rates (125 and $250 \mathrm{~kg} \mathrm{~N} \mathrm{ha}^{-1}$ year $^{-1}$ ) and on different soil types. Reported volatilization rates from urea ranged from 11.2 to $42 \%$ of $\mathrm{N}$ applied (14 to $105 \mathrm{~kg} \mathrm{~N} \mathrm{ha}^{-1}$ year ${ }^{-1}$ ), and volatilization from ammonium sulfate ranged from 0.1 to $0.4 \%$ of $\mathrm{N}$ applied $(0.1$ to $0.5 \mathrm{~kg} \mathrm{~N} \mathrm{ha}^{-1}$ year $^{-1}$ ) (Sinasamy et al. 1982; Chan and Chew 1984). Another experiment was carried out in Peru by (Bouchet 2003, unpublished data) with a lower fertilization rate $\left(85 \mathrm{~kg} \mathrm{~N} \mathrm{ha}^{-1}\right.$ year $\left.^{-1}\right)$. The study found that 4 to $16 \%$ of $\mathrm{N}$ applied in urea was volatilized (3.4 to $13.6 \mathrm{~kg} \mathrm{~N} \mathrm{ha}^{-1}$ year $^{-1}$ ), with higher volatilization under vegetation cover and no volatilization from ammonium sulfate. Therefore, given the few studies done and the high variability of the results, the magnitude of losses and the reasons for variations are uncertain. For urea, the highest values were in sandy loam soils with high application rates, and for ammonium sulfate the highest values were in clay soils with high application rates, but they did not exceed $1 \%$ of $\mathrm{N}$ applied.

Gaseous emissions of $\mathrm{N}_{2} \mathrm{O}, \mathrm{NO}_{x}$, and $\mathrm{N}_{2}$ are produced by soil microorganisms, principally through nitrification and denitrification (flux no. 14 in Fig. 2). Tropical soils are considered as important sources of $\mathrm{N}_{2} \mathrm{O}$ due to rapid $\mathrm{N}$ cycling (Duxbury and Mosier 1993). As $\mathrm{N}_{2} \mathrm{O}$ and $\mathrm{NO}_{x}$ emissions are difficult to measure and have a very high variability, very few measurements were carried out in oil palm (Corley and Tinker 2003; Banabas et al. 2008; Banabas et al. 2008; Nelson et al. 2010). Maybe due to the recent growing concern about greenhouse gases emissions, most of the measurements available were done in the 2000s and most of them involved peatlands (e.g. Melling et al. 2007). To our knowledge, only two trials were carried out under oil palm on mineral soils. They focused on $\mathrm{N}_{2} \mathrm{O}$ emissions and showed very variable results whose average values ranged from 0.01 to $7.3 \mathrm{~kg} \mathrm{~N} \mathrm{ha}^{-1}$ year $^{-1}$. Emissions tended to decrease with the age of palms and to be higher in poorly drained soils. Potential $\mathrm{N}_{2} \mathrm{O}$ emissions are high in poorly drained soils due to limited $\mathrm{N}$ uptake by plants and conditions that are conducive for denitrification.

The first study showed $\mathrm{N}_{2} \mathrm{O}$ emissions ranging from 0.01 to $2.5 \mathrm{~kg} \mathrm{~N} \mathrm{ha}^{-1}$ year $^{-1}$ in Indonesia (Ishizuka et al. 2005). The highest values were reported for young palms while the lowest were reported for old palms. Ishizuka suggested that the high emissions under young palms could result from the low 
uptake of young palms being concomitant with the application of fertilizer and the fixation of $\mathrm{N}$ by the legume cover. Conversely, the low emissions under old palms could result from the higher $\mathrm{N}$ uptake by palms and the absence of legume cover. The results also indicated that in this area, the $\mathrm{N}_{2} \mathrm{O}$ emissions were mainly determined by soil moisture. The second study showed emissions ranging from 1.36 to $7.3 \mathrm{~kg} \mathrm{~N} \mathrm{ha}{ }^{-1}$ year $^{-1}$ on two different soil types in Papua New Guinea (Banabas 2007). Banabas explained the highest emissions as being related to poor drainage of the soil.

Despite the limited number of measurements in oil palm plantations on mineral soils and the high variability of results, emissions seem to be higher over the first years of the palms. In addition, they seem to be of the same order of magnitude as those under oil palm in peatlands, e.g., average of $1.2 \mathrm{~kg} \mathrm{~N}^{-1}$ year $^{-1}$ (Melling et al. 2007); under other crops in tropical conditions, e.g., average of $1.2 \mathrm{~kg} \mathrm{~N} \mathrm{ha}^{-1}$ year $^{-1}$ (Bouwman et al. 2002); and under tropical forest, e.g., average of $3 \mathrm{~kg} \mathrm{~N}^{-1}$ year $^{-1}$ (Keller et al. 1986). However, data is lacking on the effect of spatial heterogeneity of $\mathrm{N}_{2} \mathrm{O}$ emission drivers, such as fertilizer application, soil water content, and organic matter content. Moreover, no measurements of $\mathrm{NO}_{x}$ and $\mathrm{N}_{2}$ emissions have been reported for oil palm.

In summary, $\mathrm{N}$ outputs were estimated at $0-100$ and $0.01-$ $7.3 \mathrm{~kg} \mathrm{~N} \mathrm{ha}{ }^{-1}$ year $^{-1}$ through harvest and $\mathrm{N}_{2} \mathrm{O}$ emissions, respectively, and in percentage of mineral $\mathrm{N}$ applied, 1-34, 2-15.6, 0.5-6.2, and 0.1-42, for leaching, runoff, erosion, and $\mathrm{NH}_{3}$ volatilization, respectively. The largest losses are volatilization of $\mathrm{NH}_{3}$ and leaching of $\mathrm{NO}_{3}{ }^{-}$. The results and references are synthesized in Table 3.

\section{Important fluxes and critical conditions for $\mathrm{N}$ losses}

\subsection{The most important and most uncertain fluxes}

Among the characterized fluxes, some are continuous, such as biological $\mathrm{N}$ fixation, $\mathrm{N}$ uptake, transfer of residues from plant to litter, and some are discontinuous. The discontinuous fluxes may occur one or several times per month, such as for export of fresh fruit bunches, pruning of fronds, leaching, runoff, and erosion during rainfall events; one or several times per year, such as for mineral and organic fertilizer application, $\mathrm{NH}_{3}$ volatilization after fertilizer application; or only once in the cycle, as for the felling of the whole palm (Fig. 3). Therefore, when performing an $\mathrm{N}$ budget analysis in oil palm, the choice of the timescale influences the precision of the mechanisms taken into account. Moreover, the magnitude of some fluxes differs between the crop phases, e.g., mineral fertilizer application rate is about $48-90 \mathrm{~kg} \mathrm{~N}^{-1}$ year $^{-1}$ on immature

Table 3 Summary of $\mathrm{N}$ outputs estimates from the reviewed experimental data

\begin{tabular}{|c|c|c|c|c|}
\hline Fluxes & $\begin{array}{l}\text { Estimates } \mathrm{kg} \mathrm{N} \mathrm{ha}^{-1} \text { year }^{-1} \\
\text { or } \% \text { of } \mathrm{N} \text { applied }\end{array}$ & $\begin{array}{l}\text { Variability } \\
\text { Ratio } \max / \mathrm{min}\end{array}$ & $\begin{array}{l}\text { Main controls } \\
\text { identified in literature }\end{array}$ & References \\
\hline $\begin{array}{l}\text { Export in fresh } \\
\text { fruit bunches }\end{array}$ & $\begin{array}{l}0(0-2 \text { years }) \\
30-100(>10 \text { years })\end{array}$ & $\overline{-}$ & $\begin{array}{l}\text { Age of the palms, planting } \\
\text { material, soil, and climate } \\
\text { conditions }\end{array}$ & $\begin{array}{l}\text { (Tinker 1976); } \\
\quad \text { (Corley and Tinker 2003) }\end{array}$ \\
\hline Leaching & $\begin{array}{l}10.9 \text { to } 34 \%(0-4 \text { years }) \\
1 \text { to } 4.8 \%(>5 \text { years })\end{array}$ & 34 & $\begin{array}{l}\text { Palms age, spatial repartition } \\
\text { of fertilizer placement, rainfalls, } \\
\text { and } \mathrm{N} \text { uptake rate }\end{array}$ & $\begin{array}{l}(\text { Corley and Tinker 2003) } \\
(\text { Comte et al. 2012) } \\
\text { (Omoti et al. 1983); } \\
\text { (Foong et al. 1983); } \\
\text { (Chang and Abas 1986); } \\
\text { (Foong 1993); (Ng et al. 1999); } \\
\text { (Henson 1999); } \\
\text { (Ah Tung et al. 2009) }\end{array}$ \\
\hline Runoff and erosion & $\begin{array}{l}2 \text { to } 15.6 \% \text { (runoff) } \\
0.5 \text { to } 6.2 \% \text { (erosion) }\end{array}$ & $\begin{array}{l}7.8 \text { (runoff) } \\
12.4 \text { (erosion) }\end{array}$ & $\begin{array}{l}\text { Soil permeability, slope, spatial } \\
\text { heterogeneity (soil cover) }\end{array}$ & $\begin{array}{l}(\text { Corley and Tinker 2003) } \\
(\text { Comte et al. 2012) } \\
\text { (Maena et al. 1979) } \\
\text { (Kee and Chew 1996) } \\
\text { (Banabas et al. 2008) (Ribka 2014) }\end{array}$ \\
\hline $\mathrm{NH}_{3}$ volatilization & $\begin{array}{l}\text { 4- } 42 \% \text { (urea) } \\
0.1-0.4 \% \\
\quad \text { (ammonium sulfate) }\end{array}$ & 420 & $\begin{array}{l}\text { Fertilizer type, soil texture, } \\
\text { soil cover }\end{array}$ & $\begin{array}{l}\text { (Sinasamy et al. 1982) } \\
\text { (Chan and Chew 1984); } \\
\text { (Bouchet 2003) }\end{array}$ \\
\hline $\begin{array}{l}\mathrm{NH}_{3} \text { emissions from } \\
\text { fronds and vegetation } \\
\text { cover }\end{array}$ & No data available & & & \\
\hline $\mathrm{N}_{2} \mathrm{O}$ emissions & 0.01 to 7.3 & 730 & $\begin{array}{l}\text { Soil moisture, soil drainage, } \\
\text { palms age }\end{array}$ & (Ishizuka et al. 2005) Banabas 2007 \\
\hline $\mathrm{NO}_{x}, \mathrm{~N}_{2}$ emissions & No data available & & & \\
\hline
\end{tabular}

${ }^{a}$ Review articles that may be helpful for readers to have a quick overview of each flux 
Annual fluxes of nitrogen

(kgN.ha-1 $\mathrm{yr}^{-1}$ )
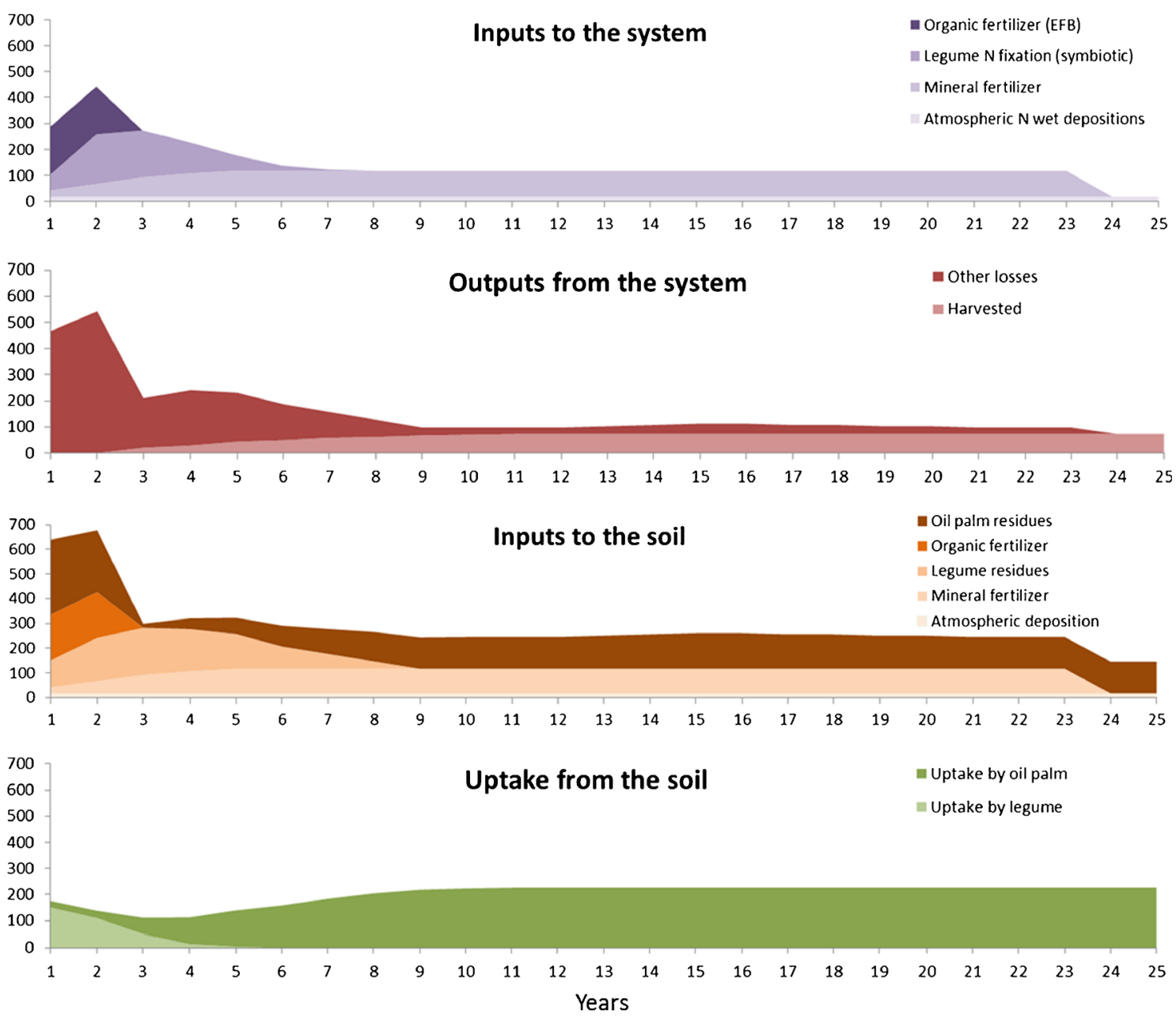

Fig. 3 Summary of the temporal patterns of $\mathrm{N}$ fluxes in the oil palm plantation. $\mathrm{N}$ fluxes vary over the crop cycle, and $\mathrm{N}$ budget must take into account this temporal variability to be precise. Annual fluxes are estimated based on mean values from Table 1 and assuming a yield of $25 \mathrm{t}$ of fresh fruit bunches ha ${ }^{-1}$ year $^{-1}$ after 10 years, applications of

palms, 56-206 $\mathrm{kg} \mathrm{N} \mathrm{ha}^{-1}$ year $^{-1}$ on mature palms, and may be zero on the oldest palms. Some fluxes occur only in one phase, such as the fluxes related to legume cover growth, which occur mainly over the first 5-7 years after planting. Thus, the crop phase should be taken into account to obtain a precise budget analysis.

The magnitude of some fluxes varies within fields because of the spatial heterogeneity of practices. For example, pruned fronds are placed in the windrows, and mineral fertilizer input depends on the method of fertilizer application but are usually spread around the weeded circle when applied manually. The effects of this spatially differentiated management on fluxes were evidenced in particular for runoff and erosion (Maena et al. 1979; Ribka 2014). Similar effects might be expected for leaching and $\mathrm{N}_{2} \mathrm{O} / \mathrm{NO}_{x}$ emissions but data is lacking. Moreover, the value of some fluxes varies between fields of
$100 \mathrm{~kg} \mathrm{~N} \mathrm{ha}^{-1}$ year $^{-1}$ of mineral $\mathrm{N}$ fertilizer (75\% ammonium sulfate, $25 \%$ urea), and of $184 \mathrm{~kg} \mathrm{~N} \mathrm{ha}^{-1}$ year $^{-1}$ of empty fruit bunches spread the first 2 years. The losses are estimated assuming that the nitrogen which entered the system is either exported through harvest or lost (no change in the $\mathrm{N}$ content of the soil over the whole cycle)

the same plantation. This is the case for the application of empty fruit bunches, which is applied to only about $10 \%$ of the mature area (Redshaw 2003). Thus, consideration of spatial heterogeneity of practices between and within fields is useful to obtain a precise budget analysis, but more research is needed for some of the fluxes.

On average, the largest $\mathrm{N}$ fluxes, of about $160-$ $640 \mathrm{~kg} \mathrm{~N} \mathrm{ha}^{-1}$ year $^{-1}$, are the felling of palms at the end of the cycle, application of palm oil mill effluent, and soil $\mathrm{N}$ mineralization. The next largest fluxes, about $60-$ $270 \mathrm{~kg} \mathrm{~N} \mathrm{ha}^{-1}$ year $^{-1}$, are uptake by the palms, application of empty fruit bunches, mineral fertilizer application, transfer of legume residues to litter, biological $\mathrm{N}$ fixation, and transfer of pruned fronds to litter. Although some of those fluxes occur only in some fields, e.g., palm oil mill effluent, only in one crop phase, e.g., biological $\mathrm{N}$ fixation and residues of legumes 
or only once in the cycle, e.g., felling of palms, we can note that the largest fluxes are internal fluxes. Moreover, there is a delay of about 6-30 months in the release of $\mathrm{N}$ from one pool to the next through microbial decomposition, e.g., for empty fruit bunches, pruned fronds, legume residues, whole palm, and dead roots. Therefore, internal fluxes and their dynamics may have important impacts on the availability of $\mathrm{N}$ for uptake or losses to the surrounding environment.

The most uncertain and least documented fluxes are $\mathrm{N}$ losses: $\mathrm{N}_{2} \mathrm{O}, \mathrm{NO}_{x}, \mathrm{~N}_{2}$ emissions, leaching, volatilization, and runoff. These high uncertainties are partly due to the difficulty of measuring these fluxes which are gaseous emissions or below-ground flux. Studies also suggested that their variability was related to soil biogeochemical properties and may therefore be significantly controlled by the spatial heterogeneity of soil properties and soil cover. An appraisal of the magnitude and uncertainty of $\mathrm{N}$ losses are presented in Fig. 4.

In summary, the largest fluxes are internal fluxes, and the most uncertain and least documented fluxes are $\mathrm{N}$ losses: $\mathrm{N}_{2} \mathrm{O}, \mathrm{NO}_{x}, \mathrm{~N}_{2}$ emissions, leaching, volatilization, and runoff. When compiling the $\mathrm{N}$ budget of oil palm systems, it is hence important to quantify the size and uncertainty of the most important fluxes, especially the internal fluxes. To reduce uncertainty, it is also important to characterize soil conditions and practices that induce high spatial variability in fluxes and understand the interactions between fluxes and between fluxes and management practices. In the following section, we focus on the main losses and their determinants.

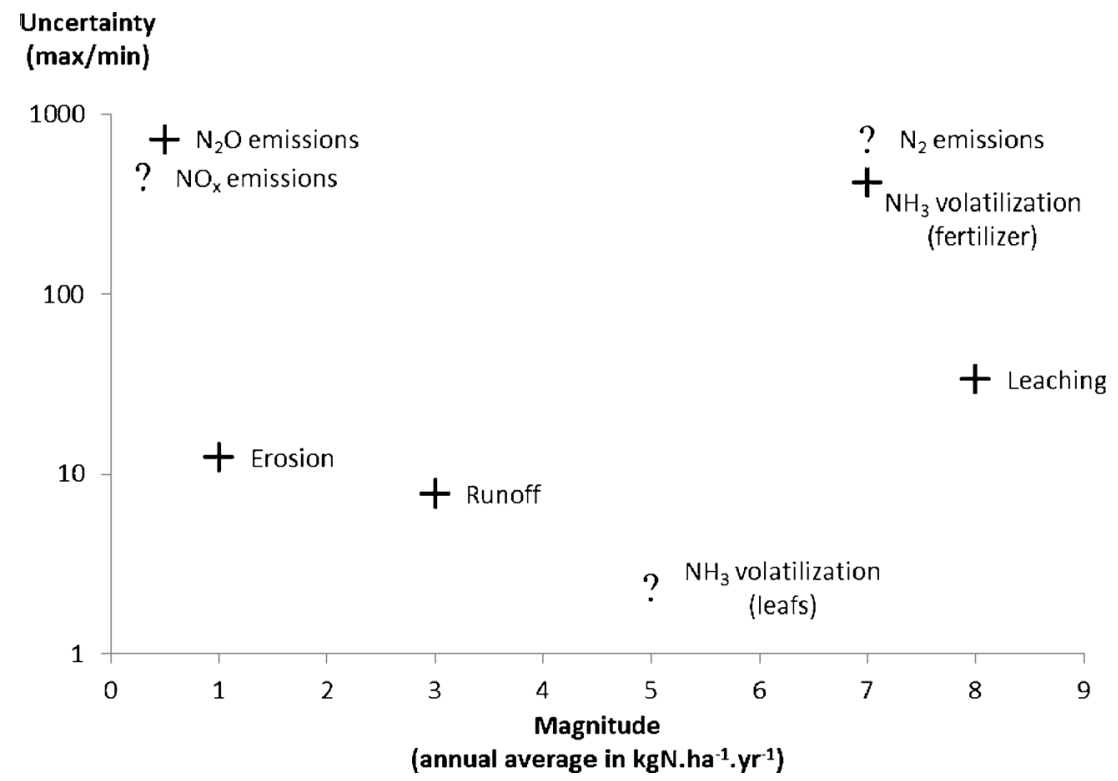

Fig. 4 Uncertainty and magnitude of the $\mathrm{N}$ losses. $\mathrm{NH}_{3}$ volatilization from fertilizer and leaching have high magnitude and high uncertainty. $\mathrm{N}_{2} \mathrm{O}$ emissions have low magnitude but high variability. Uncertainties are calculated as the $\mathrm{max} / \mathrm{min}$ ratio (logarithmic scale), and magnitudes are annual averages in $\mathrm{kg} \mathrm{N} \mathrm{ha}^{-1}$ year $^{-1}$ estimated assuming an application of $100 \mathrm{~kg} \mathrm{~N} \mathrm{ha}^{-1}$ year $^{-1}$ of mineral $\mathrm{N}$ fertilizer (see Tables 1, 2, and 3 for sources). When no quantified estimates were available, approximations of

\subsection{Critical conditions for $\mathrm{N}$ losses}

From the literature analysis, we deduced the main conditions that may lead to large $\mathrm{N}$ losses. In terms of timing, the immature phase appears to be critical. In terms of spatial heterogeneity, critical conditions occur mostly in areas with low or no soil cover and in areas where high amounts of organic and mineral fertilizers are applied (Table 4).

During the immature phase, critical concomitant conditions may generate intense short-term losses. Disturbance of vegetation, litter, and soil during felling of old palms, sowing of legumes, and planting of new palms have important impacts on soil physical properties. This may produce a peak of losses through runoff, erosion, and $\mathrm{N}_{2} \mathrm{O} / \mathrm{NO}_{\mathrm{x}}$ emissions, as measurements suggested. However, some studies reported less leaching in oil palm under legume cover compared with other vegetation covers (Agamuthu and Broughton 1985). This would support the idea that rather than enhancing $\mathrm{N}$ losses, growing legume cover might act as a regulator of the $\mathrm{N}$ content of the soil, immobilizing $\mathrm{N}$ when it is in sufficient supply in the soil and fixing $\mathrm{N}$ when it is lacking in the soil. Indeed, some studies showed that $\mathrm{N}$ fixation by legumes was significantly reduced when $\mathrm{NO}_{3}{ }^{-}$ concentration in the soil was high (Pipai 2014). As N losses during the immature phase are quite intense, their overall impact on the global plantation budget may be significant despite the short duration of the immature phase compared to the whole crop cycle.

\footnotetext{
uncertainty and magnitudes were done and are represented with a question mark. Uncertainty and magnitude of $\mathrm{NO}_{x}$ and $\mathrm{N}_{2}$ were considered to be comparable to $\mathrm{N}_{2} \mathrm{O}$, except for the magnitude of $\mathrm{N}_{2}$ which must be higher. Uncertainty and magnitude of $\mathrm{NH}_{3}$ volatilization from leaves were considered to be comparable to $\mathrm{NH}_{3}$ volatilization from annual crops (Andersen et al. 2001)
} 
Table 4 Spatio-temporal likelihood of significant N losses identified from the literature

\begin{tabular}{|c|c|c|c|c|c|}
\hline & \multirow[t]{2}{*}{ At replanting } & \multirow{2}{*}{$\begin{array}{c}\text { Immature } \\
\text { (1 to } 3 \text { years) }\end{array}$} & \multicolumn{3}{|c|}{ Mature (4 to 25 years) } \\
\hline & & & Circle & Pathway & Windrows \\
\hline $\mathrm{NH}_{3}$ volatilization & $\begin{array}{l}\text { No fertilizer } \\
\text { application }\end{array}$ & $\begin{array}{c}\text { Lower rate of } \\
\text { fertilizer }\end{array}$ & $\begin{array}{l}\text { If high rate of } \\
\text { fertilizer }\end{array}$ & $\begin{array}{l}\text { No fertilizer } \\
\text { application (if } \\
\text { manual) }\end{array}$ & $\begin{array}{l}\text { If fertilizer is } \\
\text { spread on } \\
\text { windrows }\end{array}$ \\
\hline Leaching & $\begin{array}{l}\text { High inputs } \\
\text { (trunks) / no } \\
\text { uptake }\end{array}$ & $\begin{array}{l}\text { high inputs } \\
\text { (fertilizer, } \\
\text { BNF) / low oil } \\
\text { palm / high } \\
\text { BNF uptake }\end{array}$ & $\begin{array}{c}\text { ? } \\
\text { High inputs, } \\
\text { high stem flow } \\
\text { / high root } \\
\text { density } \\
\end{array}$ & $\begin{array}{l}\text { Compacted } \\
\text { soil, no } \\
\text { fertilizer } \\
\text { application (if } \\
\text { manual) } \\
\end{array}$ & $\begin{array}{l}\text { ? } \\
\text { High N content, } \\
\text { high through fall, } \\
\text { high porosity / } \\
\text { high root density }\end{array}$ \\
\hline Runoff, erosion & No cover & $\begin{array}{c}\text { Important soil } \\
\text { cover }\end{array}$ & $\begin{array}{l}\text { No cover, high } \\
\text { stem flow, } \\
\text { compacted soil }\end{array}$ & $\begin{array}{c}\text { No cover, } \\
\text { compacted soil, } \\
\text { high } \\
\text { throughfall }\end{array}$ & $\begin{array}{l}\text { Important soil } \\
\text { cover, high } \\
\text { porosity / high } \\
\text { through fall }\end{array}$ \\
\hline $\begin{array}{l}\mathrm{N}_{2} \mathrm{O}, \mathrm{NO}_{\mathbf{x}}, \mathrm{N}_{2} \\
\text { emissions }\end{array}$ & $\begin{array}{l}\text { ? } \\
\text { High organic } \\
\text { matter } \\
\text { content, N } \\
\text { content } \\
\text { (trunks) }\end{array}$ & $\begin{array}{l}\text { High inputs } \\
\text { (fertilizer, } \\
\text { BNF) / low } \\
\text { uptake }\end{array}$ & $\begin{array}{c}? \\
\text { High stem flow, } \\
\text { high } \\
\text { compaction, } \\
\text { high N content } \\
\text { / high uptake }\end{array}$ & $\begin{array}{c}\text { ? } \\
\text { High } \\
\text { compaction, } \\
\text { high } \\
\text { throughfall }\end{array}$ & $\begin{array}{c}\text { ? } \\
\text { High water } \\
\text { content, high } \\
\text { organic matter } \\
\text { content, high N } \\
\text { content }\end{array}$ \\
\hline
\end{tabular}

Risks of losses due to critical conditions occurring in a same period or in a same area are represented in dark gray (high risk), light gray (medium risk), and white (low risk); potential risks of losses for which data is lacking are marked with question mark, and important factors influencing the risks are given. $B N F$ biological nitrogen fixation

Localization of critical conditions in particular parts of the plantations may generate large losses in small areas, which may become significant over the whole cycle. During the mature phase, inputs of mineral and organic fertilizers and palm residues are not applied evenly across the plantations. The high amounts of carbon and $\mathrm{N}$ they contain are applied over small areas, which may enhance the $\mathrm{N}$ cycling and might therefore generate hotspots of $\mathrm{N}$ losses in these areas. Large losses may occur in areas with little or no cover due to a lack of surface protection, e.g., in weeded circle and harvest pathway, as measurements showed. Moreover, the soil compaction of these areas may enhance $\mathrm{N}_{2} \mathrm{O} / \mathrm{NO}_{x}$ emissions (Ball et al. 2008; Bessou et al. 2010). The combination of low surface cover with low root activity under the harvest pathway (Nelson et al. 2006) may favor losses through leaching in this area. But more research is needed to confirm it.

\section{Discussion and key research needs}

Determination of $\mathrm{N}$ losses and their impacts is complex, as reactive $\mathrm{N}$ undergoes and is influenced by many biological transformations and is widely dispersed by hydrologic and atmospheric transport (Galloway et al. 2003). These difficulties are acute in the case of perennial cropping systems given the long crop cycle and spatial and temporal patterns. Interactions in time and space additional to those discussed in this paper are also likely. For example, Agamuthu and Broughton (1985) suggested that the presence of legume cover during the immature phase could stimulate the rooting of palms through competition and hence reduce leaching during the mature phase. Schroth et al. (2000) noted that fertilizer placement may influence the roots' lateral distribution. Thus, broadcast fertilizer application at young age may favor a more extensive lateral root development and therefore a more efficient uptake in the inter-tree space during the mature phase (Foster and Dolmat 1986). Finally, Dubos and Flori (2014) recently reported that the response time of the soil-plant system to practices may be of several years.

We reviewed all studies on experiments and $\mathrm{N}$ flux analysis in oil palm plantations that could be found in the literature. Despite our effort to gather information from multiple sources, we suppose that more data may be available in company research reports or in national publications of producing countries that were not accessible through the English language search engines examined here (Web of Knowledge, Science Direct, Agricola) nor through the authors' network.

Finally, we explored common current management practices mostly in industrial plantations. More variability surely exists across a wider range of plantation types, especially in smallholder fields (40\% in Indonesia; $>90 \%$ in Thailand in Rival 
and Levang 2013). For instance, less widespread practices exist, such as various compost processes and fertilizer applications. Moreover, there has been recently an increasing interest in diverting empty fruit bunches and palm oil mill effluent residues toward bioenergy chains (Wiloso et al. 2015). In this context, a comprehensive understanding on the efficiency of organic fertilizers, beyond a simple nutrient-based mineral equivalency, is crucial in order to avoid unexpected perverse effects such as fertility loss or increased $\mathrm{N}$ losses.

This review highlighted the extent of the knowledge gap and key research needs in the case of oil palm. In particular, it emphasized the need for comprehensive datasets on $\mathrm{N}$ dynamics taking into account the spatial and temporal heterogeneity due to the long-term perennial cycle and the varying agricultural practices. Attention should be paid notably to quantify biological $\mathrm{N}$ fixation, immobilization, and mineralization during the immature phase and after fertilizer applications. Internal fluxes are of great importance in the system and can lead to critical losses. $\mathrm{NO}_{3}{ }^{-}$leaching, notably during the immature phase, needs deeper investigations. In parallel, a great effort should be put in measuring gaseous $\mathrm{N}$ losses to reduce their uncertainty. Regarding the influence of practices on $\mathrm{N}$ fluxes, further research is needed to decipher and quantify short- and long-term effects of land preparation, planting, and fertilizer management. Notably, the role of organic fertilizers should be further investigated considering both $\mathrm{N}$ fluxes during treatment, e.g., emissions during composting and after field application. A network of experimental trials with longterm monitoring in various pedo-climatic and technical contexts would be needed in order to appraise the multidimensional variability of those fluxes.

The more knowledge on the various fluxes that accumulates, the more precise and accurate $\mathrm{N}$ budget approaches and fertilizer management tools become. Quantifying $\mathrm{N}$ fluxes also aims at identifying potential environmental impacts. Greater knowledge on $\mathrm{N}$ losses based on field measurements could serve as a basis to build up new emission factors for environmental impact assessment. Indeed, current emission factors, such as those from the IPCC guidelines, rely on datasets in which tropical crops and perennial crops are underestimated (Bouwman et al. 2002). In the view of sustainability assessment, consolidated results on $\mathrm{N}$ cycling and related potential environmental impacts should be useful to build-up agro-ecological indicators for management or certification schemes, such as RSPO, the Roundtable on Sustainable Palm Oil, and to improve impact assessments such as Life Cycle Assessments.

\section{Conclusions}

Oil palm plantations have three main peculiarities affecting $\mathrm{N}$ dynamics in a way that differs from other cropping systems: the long duration of the growing cycle, the marked spatial heterogeneity, and the large internal fluxes and pools of $\mathrm{N}$. Several studies have measured or estimated most of the various fluxes, but data is still lacking for some of them. In particular, the role of legumes during the immature phase, the complex dynamics of $\mathrm{N}$ in soils, and the impact of spatial heterogeneity of $\mathrm{N}$ losses are poorly understood. We concluded that the most uncertain $\mathrm{N}$ fluxes are $\mathrm{N}$ losses. Thus, more research into $\mathrm{N}$ losses is needed to better understand their dynamics in order to reduce losses to the environment and hence increase the economic and agro-ecological efficiency of management practices. Finally, we identified three main cases in which critical conditions may occur and enhance $\mathrm{Nr}$ losses: the immature phase, when palms are still young and legume cover is vigorous, during the mature phase in areas with sparse or no soil cover and during the mature phase where high amounts of organic and mineral fertilizers are applied. This review will serve as a baseline to analyze the suitability of existing models to assess $\mathrm{N}$ dynamics and losses in oil palm plantations and to guide further research in the field.

Acknowledgments The authors would like to thank the French National Research Agency (ANR) for its support within the frame of the SPOP project (http://spop.cirad.fr/) in Agrobiosphere program. The authors also would like to thank the editors and anonymous reviewers whose comments allowed for improving the quality of the paper.

\section{References}

Agamuthu P, Broughton WJ (1985) Nutrient cycling within the developing oil palm-legume ecosystem. Agric Ecosyst Environ 13:111-123. doi:10.1016/0167-8809(85)90054-4

Ah Tung P, Mohd Kamil Y, Nik Muhamad M et al (2009) Effect of N and $\mathrm{K}$ fertilizers on nutrient leaching and groundwater quality under mature oil palm in Sabah during the monsoon period. J Appl Sci 6:1788-1799. doi:10.3844/ajassp.2009.1788.1799

Aisueni (1987) Assessments of heterotrophic N2 fixation in the ecosystels of oil palm. Proc. of 1987 Int. O.P/P.O Conference. 672-676

Allen K, Corre MD, Tjoa A, Veldkamp E (2015) Soil nitrogen-cycling responses to conversion of lowland forests to oil palm and rubber plantations in Sumatra, Indonesia. PLoS One 10:e0133325

Amir HG, Shamsuddin ZH, Halimi MS et al (2001) Effects of Azospirillum inoculation on N2 fixation and growth of oil palm plantlets at nursery stage. J Oil Palm Res 13:42-49

Andersen J M, H D Poulsen, C F Børsting, H B Rom, S G Sommer and N J Hutchings (2001), Ammoniakemission fra landbruget siden midten af 80'erne (English: Ammonia emission from agriculture since the mid 80ies). Faglig rapport fra DMU, nr. 353, Danmarks Miljøunder-søgelser, Miljøministeriet, Copenhagen

Ball BC, Crichton I, Horgan GW (2008) Dynamics of upward and downward $\mathrm{N}_{2} \mathrm{O}$ and $\mathrm{CO}_{2}$ fluxes in ploughed or no-tilled soils in relation to water-filled pore space, compaction and crop presence. Soil Till Res 101:20-30

Banabas M (2007) Study of nitrogen loss pathways in oil palm (Elaeis guineensis Jacq.) growing agro-ecosystems on volcanic ash soils in Papua New Guinea: a thesis presented in partial fulfilment of the 
requirements for the degree of Doctor of Philosophy in Soil Science at Massey University, Palmerston North, New Zealand.

Banabas M, Turner M, Scotter D, Nelson P (2008) Losses of nitrogen fertiliser under oil palm in Papua New Guinea: 1. Water balance, and nitrogen in soil solution and runoff. J Soil Res 46:332-339. doi:10. 1071/SR07171

Bessou C, Mary B, Léonard J et al (2010) Modeling soil compaction impacts on nitrous oxide emissions in arable fields. E J Soil Sci 61:348-363. doi:10.1111/j.1365-2389.2010.01243.x

Bessou C, Chase LDC, Henson IE et al (2014) Pilot application of PalmGHG, the Roundtable on Sustainable Palm Oil greenhouse gas calculator for oil palm products. J Clean Prod 73:136-145. doi:10.1016/j.jclepro.2013.12.008

Bouchet L (2003) Evaluation de la perte d'azote par volatilization chez le palmier à huile Premiers éléments destinés à une évaluation Agroenvironnementale. Supagro Montpellier-France

Bouwman AF, Boumans LJM, Batjes NH (2002) Emissions of $\mathrm{N}_{2} \mathrm{O}$ and NO from fertilized fields: summary of available measurement data: summary of $\mathrm{NO}$ and $\mathrm{N}_{2} \mathrm{O}$ measurement data. Glob Biogeochem Cycles 16:6-1-6-13. doi:10.1029/2001GB001811

Broughton WJ, Earp DA, Newall W (1977) Effect of various covers on the performance of Elaeis guineensis (Jacq.) on different soils. International developments in oil palm. 501-525

Caliman JP, Daniel C, Tailliez B (1994) La nutrition minérale du palmier à huile. Plant Rech Dev 1:36-54

Caliman JP, Hardianto J, Ng M, others (2001a) Strategy for fertilizer management during low commodity price. In: Cutting-edge technologies for sustained competitiveness: Proceedings of the 2001 PIPOC International palm oil congress, agriculture conference, Kuala Lumpur, Malaysia, 20-22 August 2001. Malaysian Palm Oil Board (MPOB), pp 295-312

Caliman JP, Martha B, Saletes S (2001b) Dynamics of nutrient release from empty fruit bunches in field conditions and soil characteriztics changes. In: Cutting-edge technologies for sustained competitiveness: Proceedings of the 2001 PIPOC International palm oil congress, agriculture conference, Kuala Lumpur, Malaysia, 20-22 August 2001. Malaysian Palm Oil Board (MPOB), pp 550-556

Caliman JP, Togatorop E, Martha B et al (2002) Aerial fertilization of oil palm. Better Crops Int 16:10

Carron MP, Auriac Q, Snoeck D et al (2015) Spatial heterogeneity of soil quality around mature oil palms receiving mineral fertilization. Eur J Soil Biol 66:24-31. doi:10.1016/j.ejsobi.2014.11.005

Chan KS, Chew PS (1984) Volatilization losses of urea on various soils under oil palm. In: Proceedings of seminar on fertilizers in Malaysian agriculture (Chew et al. eds.). Malaysian Society of Soil Science and Universiti Pertanian Malaysia, Kuala Lumpur. pp 91-103

Chang KC, Abas Z (1986) Leaching losses of $\mathrm{N}$ and $\mathrm{K}$ fertilisers from mature fields of perennial crops in Malaysia-a review of local work. Planter 62:468

Chew TA, Isa AB, bin Mohayidin MG (1999) Sago (Metroxylon sagu Rottboll), the forgotten palm. J Sustain Agric 14:5-17. doi:10.1300/ J064v14n04 03

Chiu SB (2004) Mucuna bracteata-dry matter conversion and decay rate of litter. Planter 80:461-464

Choo YM, Muhamad H, Hashim Z et al (2011) Determination of GHG contributions by subsystems in the oil palm supply chain using the LCA approach. Int J Life Cycle Assess 16:669-681. doi:10.1007/ s11367-011-0303-9

Comte I, Colin F, Whalen JK, et al. (2012) Agricultural practices in oil palm plantations and their impact on hydrological changes, nutrient fluxes and water quality in Indonesia. In: Adv Agro. Elsevier, pp $71-124$

Corcodel L, Farinet JL, Testiati E et al (2003) ATP 2001/10: Méthodes d'évaluation de l'impact agronomique et environnemental du recyclage agricole des déchets agro-industriels- rapport intermédiaire de recherche. CIRAD, Montpellier

Corley RHV (2009) How much palm oil do we need? Environ Sci Policy 12:134-139. doi:10.1016/j.envsci.2008.10.011

Corley RHV, Tinker PBH (2003) The oil palm, 4th edn. Blackwell, UK

Corley RHV, Gray BS, Kee NS (1971) Productivity of the oil palm (Elaeis guineensis Jacq.) in Malaysia. Exp Agric 7:129-136

Dubos B, Flori A (2014) Persistence of mineral fertility carried over from the first crop cycle in two oil palm plantations in South America. Oil Palm Bull 8-15.

Dufrêne E (1989) Photosynthèse, consommation en eau et modélisation de la production chez le palmier à huile. These Dr En Sci Univ Paris Sud Orsay 117-119.

Duxbury JM, Mosier AR (1993) Status and issues concerning agricultural emissions of greenhouse gases. Agri Dim Glob Clim Change $229-258$

FAO (2004) Fertilizer use by crop in Malaysia. FAO (Rome). http://www. fao.org/docrep/007/y5797e/y5797e00.HTM

Foley JA, Ramankutty N, Brauman KA et al (2011) Solutions for a cultivated planet. Nature 478:337-342. doi:10.1038/nature10452

Foong SF (1993) Potential evaporation, potential yields and leaching losses of oil palm. In: Basiron Y, Jalani S, Chang KC, Cheah SC, Henson IE, Kamarudin N, Paranjothy K, Rajanaidu N, Tayeb D (eds) Proceeding of the 1991 PORIM international palm oil conference. Agriculture Palm Oil Research Institute, Kuala Lampur, pp 105-119

Foong SF, Syed Sofi SO, Tan PY (1983) A lysimetric simulation of leaching losses from an oil palm field. In: Proceedings of the seminar on fertilizers in Malaysian agriculture. Malaysian Society of Soil Science, Kuala Lumpur. pp 45-68

Forde S (1972) Effect of dry season drought on uptake of radioactive phosporous by surface roots of the oil palm (Elaeis guineensis Jacq.). Agron J 64:622-623

Foster H (2003) Assessment of oil palm fertiliser requirements. In: T. H. Fairhurst and R. Hardter (Eds.), Oil palm-management for large and sustainable yields. Potash and Phosphate Institute, pp 231-257

Foster HL, Dolmat MTH (1986) The effect of different methods of placement and frequency of application of fertilizer to oil palm on an inland soil in Peninsular Malaysia. PORIM Bulletin 12.

Foster HL, Parabowo NE (2003) Efficient use of fertilisers in oil palm for increased productivity in North Sumatra. In: Proceedings of the PIPOC 2003 international palm oil congress (Agriculture). Malaysian Palm Oil Board: Kuala Lumpur, Malaysia, Putrajaya Marriott Hotel, Putrajaya, Malaysia

Galloway JN, Schlesinger WH, Levy H et al (1995) Nitrogen fixation: anthropogenic enhancement-environmental response. Glob Biogeochem Cycles 9:235-252. doi:10.1029/95GB00158

Galloway JN, Aber JD, Erisman JW et al (2003) The nitrogen cascade. Bioscience 53:341-356

Galloway JN, Townsend AR, Erisman JW et al (2008) Transformation of the nitrogen cycle: recent trends, questions, and potential solutions. Science 320:889-892. doi:10.1126/science.1136674

Galloway JN, Leach AM, Bleeker A, Erisman JW (2013) A chronology of human understanding of the nitrogen cycle. Philos Trans R Soc B Biol Sci 368:20130120. doi:10.1098/rstb.2013.0120

Giller KE, Fairhurst T (2003) Legume cover plants. TH Fairhurst R Härdter Potash Phosphate Inst Potash Phosphate Inst Can Int Potash Inst Singap 151-161

Goh K-J, Härdter R (2003) General oil palm nutrition. Oil Palm Manag Large Sustain Yields Fairhurst Härdter Eds PPIPPIC-IPI Singap 191-230.

Goh KJ, Po SB (2005) Fertilizer recommendation systems for oil palm: estimating the fertilizer rates. In: Proceedings of MOSTA best practices workshops-agronomy and crop management. Malaysian Oil Scientists' and Technologists' Association 
Goh K-J, Härdter R, Fairhurst T (2003) Fertilizing for maximum return. In: Fairhust T, Hardter R (eds) Oil Palm Management for Large and Sustainable Yields. PPI, PPIC and IPI. Potash \& Phosphate Institute, pp 279-306

Gurmit S, Manoharan S, Toh TS (1990) United plantations' approach to palm oil mill by-product management and utilization. In: Proceedings of the 1989 POROM international palm oil development conference-agriculture. Palm Oil Research Institute of Malaysia, Kuala Lumpur. pp 225-234

Gurmit S, Kow DL, Lee KH et al (1999) Empty fruit bunches as mulch. Oil Palm Environ-Malays Perspect 171-183

Hansen S (2005) Feasibility study of performing an life cycle assessment on crude palm oil production in Malaysia ( 9 pp). Int J Life Cycle Assess 12:50-58. doi:10.1065/lca2005.08.226

Hansen S (2007) Feasibility study of performing an life cycle assessment on crude palm oil production in Malaysia (9 pp). Int J Life Cycle Assess 12:50-58

Hartley CWS (1988) The botany of oil palm. Oil Palm 3:47-94

Henson IE (1999) Comparative ecophysiology of oil palm and tropical rainforest. In: Oil palm and the environment-a Malaysian perspective (Ed. by Gurmit Singh et al.). Oil Palm Growers' Council, Kuala Lumpur, Malay, pp 9-39

Henson IE (2004) Modelling carbon sequestration and emissions related to oil palm cultivation and associated land use change in Malaysia. MPOB Technology 27

Henson IE, Chai SH (1997) Analysis of oil palm productivity. II. Biomass, distribution, productivity and turnover of the root system. Elaeis 9:78-92

Holloway JM, Dahlgren RA (2002) Nitrogen in rock: occurrences and biogeochemical implications. Glob Biogeochem Cycles 16:1118. doi:10.1029/2002GB001862

IAEA (1975) Root activity patterns of some tree crops. International Atomic Energy Agency, Vienna, Austria

Ishizuka S, Iswandi A, Nakajima Y et al (2005) The variation of greenhouse gas emissions from soils of various land-use/cover types in Jambi province, Indonesia. Nutr Cycl Agroecosystems 71:17-32. doi:10.1007/s10705-004-0382-0

Jourdan C, Rey H (1997) Architecture and development of the oil-palm (Elaeis guineensis Jacq.) root system. Plant Soil 189:33-48

Jourdan C, Thongo M'Bou A, Nodichao L, et al. (2003) Fine root dynamics and turnover within tropical perennial plantations. Third International Symposium on Dynamics of Physiological Processes in Woody Roots. Perth, Australia, 2003.

Kee K-K (2004) Nutrient reserves and recycling from oil palm trunks at replanting. In: Proceedings of the fourth international crop science congress on new direction for a diverse planet, Brisbane. www. cropscience. org. auS. p 06

Kee KK, Chew PS (1996) Nutrient losses through surface runoff and soil erosion -implications for improved fertiliser efficiency in mature oil palms. In: Ariffin A, Wahid MB, Rajanaidu N, Tayeb D, Paranjothy K, Cheah SC, Chang KC, Ravigadevi S (eds) Proceedings of the PORIM international palm oil congress. Palm Oil Research Institute of Malaysia, Kuala Lampur, pp 153-169

Kee KK, Chew PS, Gan HH, Goh KJ (1998) Validation of a site yield potential model for oil palms in Malaysia. In: 1998 International oil palm conference, Bali (Indonesia), 23-25 Sep 1998. Puslit Kelapa Sawit

Keller M, Kaplan WA, Wofsy SC (1986) Emissions of $\mathrm{N}_{2} \mathrm{O}, \mathrm{CH}_{4}$ and $\mathrm{CO}_{2}$ from tropical forest soils. J Geophys Res Atmospheres 19842012 91:11791-11802

Khalid H, Zin ZZ, Anderson JM (1999a) Quantification of oil palm biomass and nutrient value in a mature plantation. I. Above-ground biomass. J Oil Palm Res 11:23-32

Khalid H, Zin ZZ, Anderson JM (1999b) Quantification of oil palm biomass and nutrient value in a mature plantation. II. Belowground biomass. J Oil Palm Res 11:63-71
Khalid H, Zin ZZ, Anderson JM (1999c) Mineralization of soil organic carbon and nitrogen in relation to residue management following replanting of an oil palm plantation. J Oil Palm Res 11:72-88

Khalid H, Zin ZZ, Anderson JM (2000) Decomposition processes and nutrient release patterns of oil palm residues. J Oil Palm Res 12: 46-63

Lamade E, Djegui N, Leterme P (1996) Estimation of carbon allocation to the roots from soil respiration measurements of oil palm. Plant Soil 181:329-339. doi:10.1007/BF00012067

Lee JSH, Abood S, Ghazoul J, Barus B, Obidzinski K, Koh LP (2014a) Environmental impacts of large-scale oil palm enterprises exceed that of smallholdings in Indonesia: forest loss from Sumatra's oil palm industry. Conserv Lett 7:25-33. doi:10.1111/ conl.12039

Lee JSH, Ghazoul J, Obidzinski K, Koh LP (2014b) Oil palm smallholder yields and incomes constrained by harvesting practices and type of smallholder management in Indonesia. Agron Sustain Dev 34:501513. doi:10.1007/s13593-013-0159-4

Lehmann J (2003) Subsoil root activity in tree-based cropping systems. In: Roots: the dynamic interface between plants and the Earth. Springer, pp 319-331

Lim (1999) Land application of oil palm mill effluent. In: Oil palm and the environment. A Malaysian perspective. Ed Gurmit Singh, Lim Lim Huan, Teo Leng, David Lee Kow. pp 153-169

Lim KC, Zaharah AR (2000) Decomposition and N \& K release by oil palm empty fruit bunches applied under mature palms. J Oil Palm Res 12:55-62

Lord S, Hoare MK, Thompson NM (2002) Composting for zero discharge-NBPOL's solution. IOPRI, Bali, Indonesia, p 11

Maena LM, Thong KC, Ong TS, Mokhtaruddin AM (1979) Surface wash under mature oil palm. In: Pushparajah E (ed) Proceedings of the symposium on water agriculture in Malaysia. Malaysian Society of Soil Science, Kuala Lampur, pp 203-216

Mather TA, Pyle DM, Allen AG (2004) Volcanic source for fixed nitrogen in the early Earth's atmosphere. Geology 32:905-908. doi:10. 1130/G20679.1

Meisinger JJ, Randall GW (1991) Estimating nitrogen budgets for soil-crop systems. Manag Nitrogen Groundw Qual Farm Profitab 85-124

Melling L, Hatano R, Goh KJ (2007) Nitrous oxide emissions from three ecosystems in tropical peatland of Sarawak, Malaysia. Soil Sci Plant Nutr 53:792-805. doi:10.1111/j.1747-0765.2007.00196.x

Mohammed AT, Zakaria ZZ, Dolmat MT et al. (1991) Relative efficiency of urea to sulfate of ammonia in oil palm: yield response and environmental factors. PORIM intl. palm oil conference. Kuala Lumpur. 340-348

Moradi A, Teh CBS, Goh KJ et al (2014) Decomposition and nutrient release temporal pattern of oil palm residues. Ann Appl Biol 164: 208-219. doi:10.1111/aab.12094

Nelson PN, Banabas M, Scotter DR, Webb MJ (2006) Using soil water depletion to measure spatial distribution of root activity in oil palm (Elaeis guineensis Jacq.) plantations. Plant Soil 286:109-121. doi: 10.1007/s11104-006-9030-6

Nelson PN, Webb MJ, Orrell I et al (2010) Environmental sustainability of oil palm cultivation in Papua New Guinea. Aust Centre Int Agric Res 75:67

Nelson PN, Webb MJ, Banabas M, Nake S, Goodrick I, Gordon J, O'Grady D, Dubos B (2014) Methods to account for tree-scale variation in soil- and plant-related parameters in oil palm plantations. Plant Soil 374:459-471. doi:10.1007/s11104-013-1894-7

Nelson PN, Banabas M, Goodrick I, et al. (2015) Soil sampling in oil palm plantations: a practical design that accounts for lateral variability at the tree scale. Plant Soil 1-9. doi: 10.1007/s11104-0152490-9 
Ng SK (1977) Review of oil palm nutrition and manuring. Scope for greater economy in fertilizer usage. Oleagineux 32:197-209

Ng SK, Thamboo S (1967) Nutrient contents of oil palms in Malaysia. I. Nutrients required for reproduction: fruit bunch and male inflorescences. Malay Agric J 46:3-45

Ng SK, Thamboo S, de Souza P (1968) Nutrient contents of oil palms in Malaysia. II. Nutrients in vegetative tissues. Malay Agric J 46: 332-391

Ng HCP, Chew PS, Goh KJ, Kee KK (1999) Nutrient requirements and sustainability in mature oil palms-an assessment. Planter 75: 331-345

Ng SK, Uexküll H von, Härdter R (2003) Botanical aspects of the oil palm relevant to crop management. Oil Palm Manag Large Sustain Yields. T Fairhurst R Härdter Eds 13-26.

Noordwijk, M. van, Lusiana, B., Khasanah, N. 'matul, 2004. Wanulcas 3.01: background on a model of water, nutrient, and light capture in agroforestry systems. World Agroforestry Centre : International Centre for Research in Agroforestry, Bogor, Indonesia.

O Legg J, J Meisinger J (1982) Soil nitrogen budgets. Nitrogen Agric Soils 503-566

Oenema O, Kros H, de Vries W (2003) Approaches and uncertainties in nutrient budgets: implications for nutrient management and environmental policies. Eur J Agron 20:3-16. doi:10.1016/S1161-0301(03) 00067-4

Ollivier J (2011) Rapport d'Expertise 6-20 Avril 2011-Marborges. Para, Brésil

Ollivier J, Lamade E, Dubos B et al (2013) Hacia un diagnostico nutricional preciso para la palma de aceite, teniendo en cuenta el origen del material de siembra. Palmas 34:203-220

Om AC, Ghazali AHA, Keng CL, Ishak Z (2009) Microbial inoculation improves growth of oil palm plants (Elaeis guineensis Jacq.). Trop Life Sci Res 20:71

Omoti U, Ataga DO, Isenmila AE (1983) Leaching losses of nutrients in oil palm plantations determined by tension lysimeters. Plant Soil 73: 365-376.

Pipai R (2014) Biological nitrogen fixation by cover legumes under oil palm plantations in Papua New Guinea. Available at https:// digital.library.adelaide.edu.au/dspace/bitstream/2440/85198/3/ 02whole.pdf. Accessed 16 Mar 2015

Prévot P, Ollagnier M (1957) Méthode d'utilisation du diagnostic foliaire. In: Analyse des plantes et problèmes des fumures minérales. IRHO, Paris, pp 177-192

Pushparajah E (1981) Nitrogen cycle in rubber (Hevea) cultivation. In: Nitrogen cycling in South-East Asian wet monsoonal ecosystems. Proceedings of a regional workshop arranged by the SCOPE/UNEP international nitrogen unit of the Royal Swedish Academy of Sciences and the Chiang Mai Univ., Thailand, 5-10 Nov 1979. Australian Academy of Science, pp 101-108

Pushparajah E, Chew PS (1998) Integrated nutrient management for sustaining high yield of plantation tree crops in tropical Asia. Proc. Soil sci. Congr, Montpellier, In

Rasiah V, Armour JD, Menzies NW et al (2003) Nitrate retention under sugarcane in wet tropical Queensland deep soil profiles. Soil Res 41: $1145-1161$

Redshaw M (2003) Utilization of field residues and mill by-products. Oil Palm Manag Large Sustain Yields Singap PPI PPIC 307-320

Reed SC, Cleveland CC, Townsend AR (2011) Functional ecology of free-living nitrogen fixation: a contemporary perspective. Annu Rev Ecol Evol Syst 42:489-512. doi:10.1146/annurev-ecolsys102710-145034

Reis VM, Baldani JI, Baldani VLD, Dobereiner J (2000) Biological dinitrogen fixation in Gramineae and palm trees. Crit Rev Plant Sci 19:227-247. doi:10.1080/07352680091139213
Ribka Sionita (2014) water run-off, soil erosion and nutrient losses: impact of slope and ground vegetation. http:/icope-series.com/2014oral-abstract/09\%20-\%20TS04\%20RibkaErosion-JPC-rev1022014.pdf. Accessed 10 Nov 2014

Rival A, Levang P (2013) Palms of controversies: oil palm and development challenges. CIFOR, Bogor, Indonesia

Rosenani AB, Hoe SF (1996) Decomposition of oil palm empty fruit bunches in the field and mineralization of nitrogen. In: Hofman G, Vermoesen A, Cleemput OV (eds) Progress in nitrogen cycling studies. Springer, Netherlands, pp 127-132

Ruiz E, López DLM (2014) Revisión de literatura sobre beneficios asociados al uso de coberturas leguminosas en palma de aceite y otros cultivos permanentes. Rev Palmas 35:53-64

Schmidt JH (2007) Life assessment of rapeseed oil and palm oil. Ph. D. thesis, Part 3: Life cycle inventory of rapeseed oil

Schroth G, Rodrigues MR, Angelo SAD' (2000) Spatial patterns of nitrogen mineralization, fertilizer distribution and roots explain nitrate leaching from mature Amazonian oil palm plantation. Soil Use Manag 16:222-229. doi:10.1111/j.1475-2743.2000. tb00197.x

Schuchardt F, Darnoko D, Guritno P (2002) Composting of empty oil palm fruit bunch (EFB) with simultaneous evaporation of oil mill waste water (POME). In: International oil palm conference, Nusa Dua, Bali

Silalertruksa T, Bonnet S, Gheewala SH (2012) Life cycle costing and externalities of palm oil biodiesel in Thailand. J Clean Prod 28:225232. doi:10.1016/j.jclepro.2011.07.022

Sinasamy N, Palaniappan S, Kamal RZ, SyeSofi-Syed O (1982) Sources of and response to nitrogen in oil palm cultivation. In: Seminar on nitrogen in Malaysia agriculture proceedings. Malaysian Society of Soil Science, Kuala Lumpur, pp 167-188

Singh G (1999) The Malaysian oil palm industry: progress towards zero waste and environment excellence. Bioresour Technol Sustain Agric 99:318-341

Singh G, Manohan S, Kanopathy K (1982) Commercial scale bunched mulching of oil palms. In: Proceeding: 1981 international oil palm conference. Agricultural in eighties. Palm Oil Research Institute of Malaysia and the Incorporates Society of Planters Kuala Lumpur, pp 367-377

Siregar FA, Saletes S, Caliman JP, Liwgang T (2002) Empty fruit bunch compost: processing and utilities. In: International oil palm conference: IOPRI. Bali, Indonesia. pp 27-57

Sommer R, Denich M, Vlek PL (2000) Carbon storage and root penetration in deep soils under small-farmer land-use systems in the Eastern Amazon region, Brazil. Plant Soil 219:231-241

Tan, K.S. (1976) Development, nutrient contents and productivity in oil palm on inland soils of West Malaysia. MSc, University of Singapore

Tan KS (1977) Efficient fertiliser usage for oil palm on inland soils. In: Earp DA, Newall S (eds) International developments in oil palm. Malaysian international agricultural oil palm conference, Kuala Lumpur, pp 262-288

Tinker PB (1976) Soil requirements of the oil palm. Dev Crop Sci Oil Palm Res Elsevier Amst Neth 165-181

Tinker PB, Nye PH (2000) Solute movement in the rhizosphere, Topics in sustainable agronomy. Oxford University Press, Oxford

Tinker PBH, Smilde KW (1963) Dry-matter production and nutrient content of plantation oil palms in Nigeria. Plant Soil 19:350-363. doi: 10.1007/BF01379488

Trebs I, Lara LS, Zeri LM et al (2006) Dry and wet deposition of atmospheric inorganic nitrogen in a tropical environment (Rondônia, Brazil). Atmos Chem Phys 6:447-469

Turner PD, Gillbanks RA (2003) Oil palm cultivation and management Incorporated Society of Planters

United Plantations Berhad (2006) Annual report 2005. United Plantations Berhad, Teluk Intan, Malaysia 
Vesterager JM, Østerby S, Jensen ES, Schjoerring JK (1995) Symbiotic $\mathrm{N}_{2}$-fixation by the cover crop Pueraria phaseoloides as influenced by litter mineralization. Plant Soil 177:1-10. doi:10.1007/ BF00010332

Vitousek PM, Aber JD, Howarth RW et al (1997) Human alteration of the global nitrogen cycle: sources and consequences. Ecol Appl 7:737-750

Watson CA, Atkinson D (1999) Using nitrogen budgets to indicate nitrogen use efficiency and losses from whole farm systems: a comparison of three methodological approaches. Nutr Cycl Agroecosystems 53:259-267. doi:10.1023/A:1009793120577

Wicke B, Dornburg V, Junginger M, Faaij A (2008) Different palm oil production systems for energy purposes and their greenhouse gas implications. Biomass Bioenergy 32:1322-1337
Wiloso EI, Bessou C, Heijungs R (2015) Methodological issues in comparative life cycle assessment: treatment options for empty fruit bunches in a palm oil system. Int J Life Cycle Assess 20(2): 204-216.

Xaviar A (2000) Fertiliser requirement of oil palms for high yields: some thoughts. Managing oil palm high yields: agronomic principles. Ed Goh KJ Malays Soc Soil Sci Param Agric Surv Kuala Lumpur 74-97.

Zaharah AR, Lim KC (2000) Oil palm empty fruit bunch as a source of nutrients and soil ameliorant in oil palm plantations. Malays J Soil Sci 4:51-66

Zaharah A, Sharifuddin H, Razley M, Mohd S (1986) Measurement of nitrogen fixed by Pueraria phaseoloides by $\mathrm{N}-15$ dilution technique. Pertakina 45-49. 